\title{
Sea ice and the ocean mixed layer over the Antarctic shelf seas
}

\author{
A. A. Petty ${ }^{1, *}$, P. R. Holland ${ }^{2}$, and D. L. Feltham ${ }^{3}$ \\ ${ }^{1}$ Centre for Polar Observation and Modelling, Department of Earth Sciences, University College London, \\ London, WC1E 6BT, UK \\ ${ }^{2}$ British Antarctic Survey, High Cross, Madingley Road, Cambridge CB3 0ET, UK \\ ${ }^{3}$ Centre for Polar Observation and Modelling, Department of Meteorology, University of Reading, Reading, RG6 6BB, UK \\ *now at: Earth System Science Interdisciplinary Center, University of Maryland, College Park, MD, USA
}

Correspondence to: A. A. Petty (alek.petty@noaa.gov)

Received: 15 August 2013 - Published in The Cryosphere Discuss.: 30 August 2013

Revised: 28 February 2014 - Accepted: 12 March 2014 - Published: 29 April 2014

\begin{abstract}
An ocean mixed-layer model has been incorporated into the Los Alamos sea ice model CICE to investigate regional variations in the surface-driven formation of Antarctic shelf waters. This model captures well the expected sea ice thickness distribution, and produces deep ( $>500 \mathrm{~m}$ ) mixed layers in the Weddell and Ross shelf seas each winter. This results in the complete destratification of the water column in deep southern coastal regions leading to high-salinity shelf water (HSSW) formation, and also in some shallower regions (no HSSW formation) of these seas. Shallower mixed layers are produced in the Amundsen and Bellingshausen seas. By deconstructing the surface processes driving the mixed-layer depth evolution, we show that the net salt flux from sea ice growth/melt dominates the evolution of the mixed layer in all regions, with a smaller contribution from the surface heat flux and a negligible input from wind stress. The Weddell and Ross shelf seas receive an annual surplus of mixing energy at the surface; the Amundsen shelf sea energy input in autumn/winter is balanced by energy extraction in spring/summer; and the Bellingshausen shelf sea experiences an annual surface energy deficit, through both a low energy input in autumn/winter and the highest energy loss in spring/summer. An analysis of the sea ice mass balance demonstrates the contrasting mean ice growth, melt and export in each region. The Weddell and Ross shelf seas have the highest annual ice growth, with a large fraction exported northwards each year, whereas the Bellingshausen shelf sea experiences the highest annual ice melt, driven by the advection of ice from the northeast. A linear regression analysis is performed to determine the link between the autumn/winter mixed-layer deepening and several atmospheric variables.
\end{abstract}

The Weddell and Ross shelf seas show stronger spatial correlations (temporal mean - intra-regional variability) between the autumn/winter mixed-layer deepening and several atmospheric variables compared to the Amundsen and Bellingshausen. In contrast, the Amundsen and Bellingshausen shelf seas show stronger temporal correlations (shelf sea mean interannual variability) between the autumn/winter mixedlayer deepening and several atmospheric variables.

\section{Introduction}

The continental shelf seas surrounding West Antarctica are a crucial component of the Earth's climate system. The Weddell and Ross (WR) shelf seas cool and ventilate the deep ocean (Orsi et al., 2001) and feed the global thermohaline circulation (Orsi et al., 1999; Jacobs, 2004), while the Amundsen and Bellingshausen (AB) shelf seas have been strongly implicated in the recent ocean-driven melting of the Antarctic Ice Sheet (Shepherd et al., 2004; Holland et al., 2010; Jacobs et al., 2011; Fricker and Padman, 2012; Pritchard et al., 2012; Rignot et al., 2013). This contrast in the behaviour of the shelf seas is most apparent in the clear bimodal distribution of the ocean temperature at the shelf seabed (Fig. 1), which is a result of cold, saline, oxygen-rich shelf waters (at around the surface freezing temperature of $\sim-1.9^{\circ} \mathrm{C}$ ) filling the WR shelf seas (Jacobs et al., 1970; Gill, 1973; Nicholls et al., 2009; Orsi and Wiederwohl, 2009), and Circumpolar Deep Water $(\mathrm{CDW})$, which is warm $\left(+1^{\circ} \mathrm{C}\right)$, slightly less saline, and deoxygenated, flooding onto the $\mathrm{AB}$ shelf seas 
(Talbot, 1988; Jacobs et al., 1996, 2011; Jenkins and Jacobs, 2008; Martinson et al., 2008).

The brine rejection from sea ice growth in the WR shelf seas causes a salinification and deepening of the surface mixed layer. This results in the formation of high-salinity shelf water (HSSW, $\sim-1.9^{\circ} \mathrm{C}, \sim 34.75$ ) through the complete destratification of the water column (where the surface mixed layer extends to the seabed), with the HSSW residing on the shelf for several years (Gill, 1973). In the Weddell Sea, HSSW is either advected northwards, crossing the shelf break (Gill, 1973; Foster and Carmack, 1976; Gordon et al., 1993), or it enters the Filchner-Ronne Ice Shelf cavity to the south, producing ice shelf water (ISW) as the HSSW melts the base of the ice shelf. The ISW is eventually transported north of the shelf through the Filchner depression (Foldvik et al., 2004; Wilchinsky and Feltham, 2009). A similar process takes place in the Ross Sea, where HSSW is either transported northwards past the Ross continental shelf break (Jacobs et al., 1970; Orsi et al., 1999) or is transported southwards into the Ross Ice Shelf cavity, with the resulting ISW flowing northwards, predominantly through the Glomar Challenger Trough in the central Ross shelf (Jacobs et al., 1970, 1985; Orsi and Wiederwohl, 2009). The eventual transport of the HSSW off the shelf results in the formation of Weddell Sea Bottom Water (WSBW) and Ross Sea Bottom Water (RSBW) (Orsi et al., 1999; Jacobs, 2004) which, together with Adélie Land Bottom Water (ALBW) (Williams et al., 2010) and the more recently discovered Cape Darnley Bottom Water (CDBW) (Ohshima et al., 2013), form Antarctic Bottom Water (AABW). AABW drives the bottom cell of the global thermohaline circulation, which accounts for around a third of the total ocean volume (Johnson, 2008).

ALBW and CDBW are fed by HSSW formed as a result of rapid brine release from small coastal polynyas over a narrow continental shelf region. In contrast, the HSSW source of WSBW and RSBW is formed through a combination of rapid sea ice growth in coastal polynyas and a more gradual sea ice growth over a broader continental shelf. In the Weddell Sea, the gradual brine release over the shelf is thought to be the dominant mechanism of converting modified warm deep water (MWDW) entering the shelf to HSSW (Renfrew et al., 2002; Nicholls et al., 2009). In the Ross Sea, the coastal polynyas produce significantly more sea ice (both in volume and as a fraction of the ice exported out of the shelf Drucker et al., 2011), although it is expected that the remaining sea ice growth plays a similar role to that in the Weddell Sea, through the cooling and salination of Modified Circumpolar Deep Water (MCDW). The relative size and impact of the coastal polynyas in the two regions is thought to be driven by the difference in the near-surface winds (see Fig. 2a), with low-pressure systems leading to strong southerly winds in the Ross Sea, and weaker southeasterly winds in the Weddell Sea. As well as these low-pressure systems, the WR seas also experience the coldest $\left(\sim-25^{\circ} \mathrm{C}\right)$ near-surface air temperatures over the Antarctic continental shelf in winter, due to strong katabatic winds carrying cold air to the WR coastlines from the centre of Antarctica (van Lipzig et al., 2004), which is also thought to play a key role in sea ice production and the resultant shelf water formation. As a result of these dense shelf waters, the Filchner-Ronne Ice Shelf (FRIS) in the Weddell Sea and the Ross Ice Shelf (RIS) in the Ross Sea are relatively well protected from the warm waters residing offshore in the Antarctic Circumpolar Current (ACC). A simplified schematic of the WR water masses and mixing processes is shown in Fig. 3a.

In contrast, the $\mathrm{AB}$ shelf seas are composed of $\mathrm{CDW}$ overlain by Winter Water (WW) formed from the remnants of winter mixed layers, which do not extend to the seabed here. The Bellingshausen shelf sea is thought to be flooded by CDW predominantly through eddy-shedding from the ACC (Martinson and McKee, 2012), although other mechanisms have been presented (e.g. Klinck et al., 2004). In the Amundsen Sea, CDW is thought to be transported onto the shelf predominantly through glacially carved troughs in the continental shelf seabed (Walker et al., 2007; Thoma et al., 2008; Wåhlin et al., 2010; Arneborg et al., 2012), with the CDW on-shelf flux controlled by the background ocean flow (Arneborg et al., 2012; Assmann et al., 2013) and episodic events (Thoma et al., 2008; St-Laurent et al., 2012). The variability of this warm CDW layer has been implicated in the recent rapid thinning of the ice shelves in the Amundsen and Bellingshausen seas (Shepherd et al., 2004; Holland et al., 2010; Jacobs et al., 2011; Fricker and Padman, 2012; Pritchard et al., 2012; Rignot et al., 2013; Dutrieux et al., 2014). Variability in the thickness of the CDW layer can either be driven by variable upwelling at the shelf break (Thoma et al., 2008) or by variable mixing of cold waters from above (Holland et al., 2010). An understanding of the formation of waters overlying the $\mathrm{CDW}$ is therefore important in understanding future ice loss from the Antarctic Ice Sheet. A simplified schematic of the AB water masses and mixing processes is shown in Fig. $3 \mathrm{~b}$.

The difference in shelf water properties between the WR and $\mathrm{AB}$ shelf seas could be due to the close proximity of warm CDW from the southern boundary of the ACC, which is situated just offshore of the shelf break in these regions (as shown in Fig. 1). However, the AB shelf seas also experience warmer $\left(\sim-15^{\circ} \mathrm{C}\right)$ surface air temperatures in winter, which, along with several other atmospheric differences, was demonstrated by Petty et al. (2012) to be sufficient to explain the lack of shelf water formation in these two regions.

Modelling studies have demonstrated the crucial role of sea ice in controlling the upper ocean characteristics of the Bellingshausen (Meredith et al., 2004; Holland et al., 2010) and Amundsen (Assmann et al., 2005) seas, and in the formation of shelf waters in the Weddell (Timmermann et al., 2002) and Ross (Assmann and Timmermann, 2005) seas. Despite these regional modelling studies, to our knowledge a consistent modelling approach focusing on all four shelf sea regimes has yet to be undertaken. This study seeks to build 


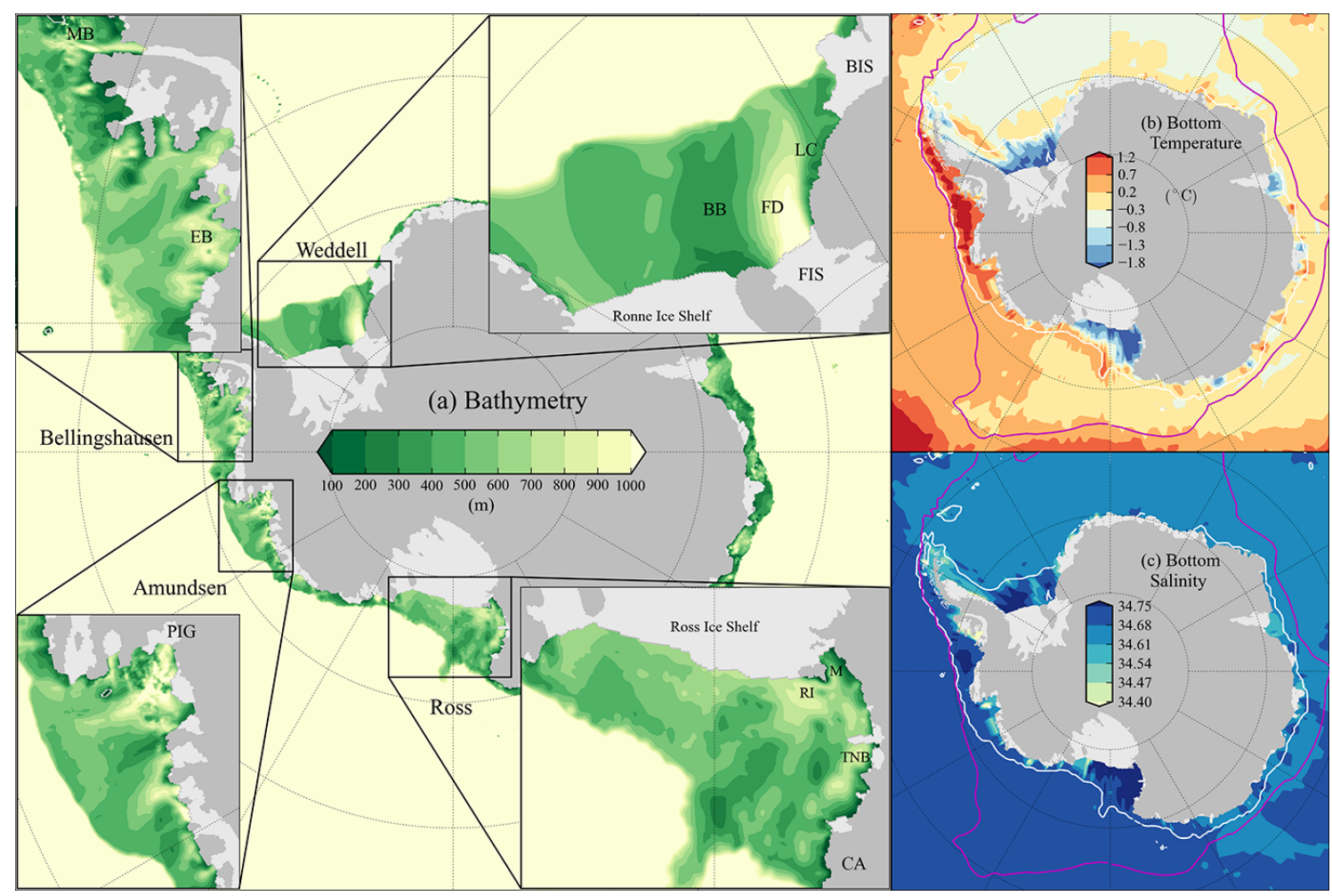

Fig. 1. (a) Bathymetry, (b) bottom temperature and (c) salinity of the Southern Ocean. Bathymetry and land mask are taken from the RTOPO data set (Timmermann et al., 2010). Ocean data are taken from the World Ocean Atlas (2009) temperature (Antonov et al., 2010) and salinity (Locarnini et al., 2010) data sets. The white line in (b) and (c) is the $1000 \mathrm{~m}$ isobath contour. The southern boundary of Upper Circumpolar Deep Water (magenta line) taken from Orsi et al. (1995) is used to define the southern boundary of the Antarctic Circumpolar Current in panels (b) and (c). BB: Berkner Bank, FD: Filchner Depression, FIS: Filchner Ice Shelf, BIS: Brunt Ice Shelf, LC: Luitpold Coast, MB: Marguerite Bay, EB: Eltanin Bay, PIG: Pine Island Glacier, RI: Ross Island, MS: McMurdo Sound, TNB: Terra Nova Bay, CA: Cape Adare.

on these earlier approaches by using a sophisticated sea ice model to study how regional differences in the atmosphere and sea ice might control the mixed-layer evolution in these four important climatic regions.

The paper is structured as follows: Sect. 2 presents the model formulation; Sect. 3 discusses the model results; and concluding remarks are given in Sect. 4.

\section{Model formulation}

In this study a variable mixed-layer ocean model is incorporated into the Los Alamos sea ice model CICE (version 4.1). The standard CICE configuration includes five ice thickness categories, one snow thickness category and open water. The sea ice thermodynamics are based on Bitz and Lipscomb (1999) which takes into account internal brine pockets within the sea ice and is an energy-conserving update to the Maykut and Untersteiner (1971) sea ice surface energy balance. The ice dynamics are based on the viscous-plastic (VP) rheology of Hibler (1979), updated to the more numerically efficient elastic-viscous-plastic (EVP) rheology of Hunke and Dukowicz (1997). A full description of the Los
Alamos CICE sea ice model can be found in its user manual (Hunke and Lipscomb, 2010).

In the standard CICE configuration, the mixed-layer depth is set to a constant value (default of $30 \mathrm{~m}$ ), the mixed-layer salinity is prescribed, and the mixed-layer temperature is prognostic, with the option of restoring this temperature towards data. A deep-ocean/mixed-layer heat flux is prescribed from data. By adapting CICE to include a variable mixed layer, we allow the mixed-layer depth, temperature and salinity to evolve, based on the calculated surface and deep-ocean fluxes as described below.

We use a bulk mixed-layer model based on Kraus and Turner (1967) and Niiler and Kraus (1977), similar to that described in Petty et al. (2012). The use of a simple bulk mixed layer reduces the computational cost of studying the formation of shelf waters, and enables us to have a complete understanding of all aspects of the model results. The ocean below the mixed layer is relaxed towards observations, rather than modelled, which allows us to remove the impact of variable ocean dynamics and thus isolate the effect of surface forcings. 


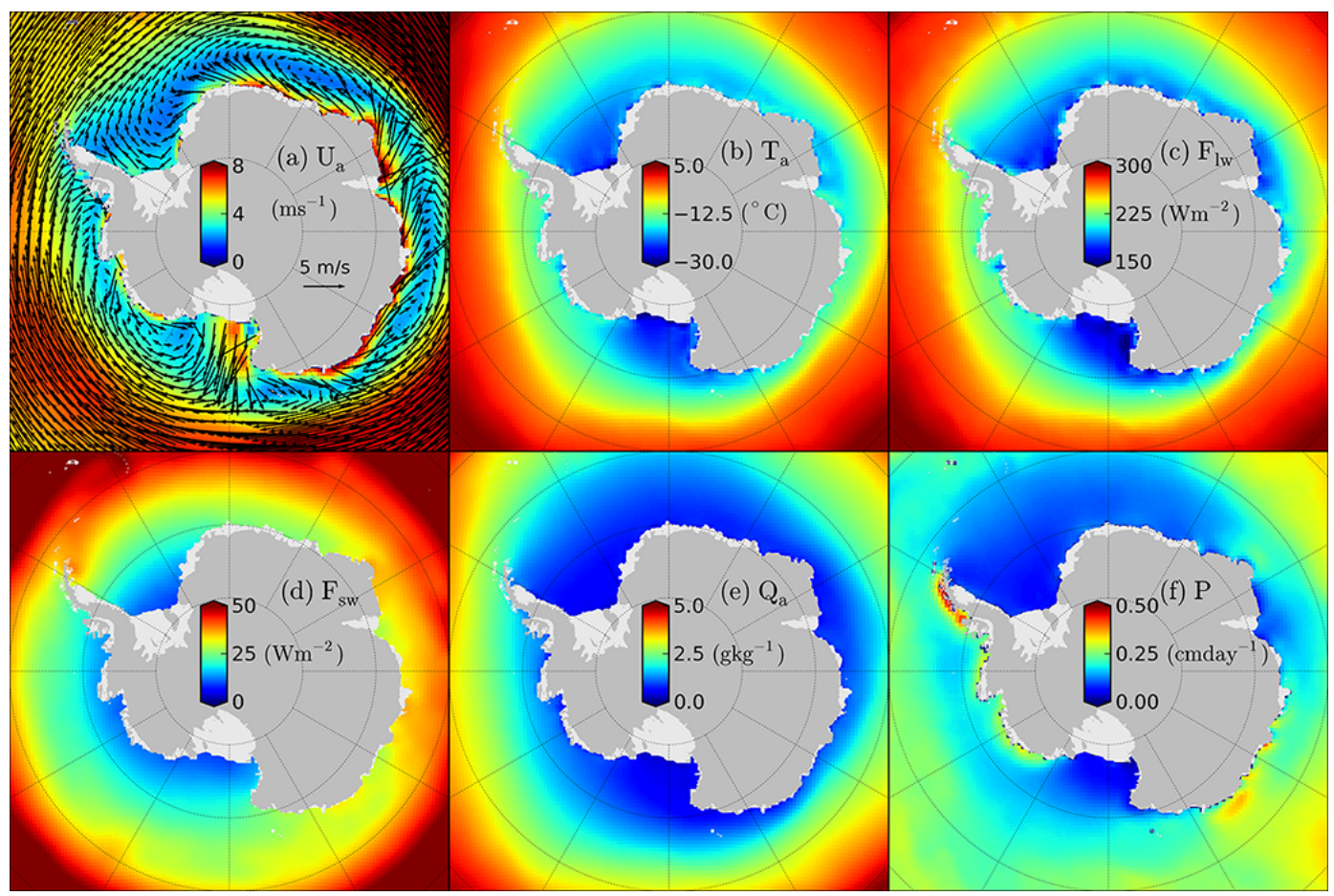

Fig. 2. Mean (1980-2011) ERA-Interim (Dee et al., 2011) winter (July-September, JAS) atmospheric forcing. (a) $10 \mathrm{~m}$ wind speed, overlain with $10 \mathrm{~m}$ wind vectors (every third grid point), (b) $2 \mathrm{~m}$ air temperature, (c) incoming long-wave radiation, (d) incoming short-wave radiation, (e) $2 \mathrm{~m}$ specific humidity, (f) total precipitation (snow and rain).

The sea ice has been adapted substantially from that of Petty et al. (2012), so the following section discusses the $\mathrm{CICE} /$ mixed-layer model that has been developed. The zerodimensional mixed-layer model has no horizontal interaction, so the description below applies to each grid cell within CICE. Constants and fixed parameters referred to in this section are listed in Table 1, while a full list of model variables is given in the Supplement (Table S1).

\subsection{Model description}

\subsubsection{Heat and salt fluxes}

While CICE treats the mixed layer and surface layer as analogous, we use a simple two-layer ocean for our temperature calculations, consisting of a fixed depth ocean surface layer $h_{\mathrm{S}}=10 \mathrm{~m}$ and a variable mixed layer $h_{\text {mix }}$ below, as shown in Fig. 4. The surface temperature layer exchanges heat with the variable-depth mixed layer below and with the sea ice and atmosphere above, as described later in this section. Adding this surface temperature layer allows us to model the expected rapid change in temperature of the ocean surface, improving the fit of modelled ice concentration to observations, while still providing us with a simple and computationally efficient sea-ice/mixed-layer model to use for this study. Without this surface layer, the mixed layer and thus surface temperature often remained slightly above freezing when the mixed layer was deep (order of several hundred metres) and entraining heat (with this heat being distributed instantaneously throughout the mixed layer), hindering the formation of sea ice in winter. Note that for simplicity the salinity calculations ignore this surface layer and treat the mixed-layer salinity and surface salinity as the same, as small changes in the surface salinity will not have the same impact on the sea ice growth and melt compared to surface temperature.

The heat flux into the ocean surface layer from the ice and open-ocean fractions (all fluxes are positive downwards) is calculated as

$$
\begin{aligned}
F_{\text {surface }} & =(1-A)\left(F_{\text {sens }}^{\mathrm{o}}+F_{\text {lat }}^{\mathrm{o}}+F_{\text {lwout }}^{\mathrm{o}}+F_{\text {lwin }}^{\mathrm{o}}+F_{\text {swabs }}^{\mathrm{o}}\right) \\
& +A\left(F_{\text {ice }}+F_{\text {swthru }}\right),
\end{aligned}
$$

where $F_{\text {sens }}^{\mathrm{o}}$ is the sensible heat flux between the atmosphere to the open-ocean surface, $F_{\text {lat }}^{o}$ is the latent heat flux between the atmosphere and the open-ocean surface, $F_{\text {lwout }}^{\mathrm{o}}$ is the black-body heat flux from the open-ocean surface to the atmosphere, $F_{\text {lwin }}^{\mathrm{o}}$ is the downward long-wave radiative heat flux, $F_{\text {swabs }}^{\mathrm{o}}$ is the downward short-wave radiative heat flux calculated as a sum over four radiative categories (direct and diffuse, visible and near-infrared) with varying albedo parametrisations, $F_{\text {ice }}$ is the heat flux from the ocean surface to the base of the ice (aggregated over all ice categories/thicknesses), and $F_{\text {swthru }}$ is the short-wave radiative heat flux that passes through the ice and is absorbed by the 
Table 1. Constants and parameters referred to in the model description

\begin{tabular}{lll}
\hline \multicolumn{3}{c}{ Constants } \\
\hline$\alpha$ & thermal expansion coefficient & $5.82 \times 10^{-5} \mathrm{~K}^{-1}$ \\
$\beta$ & saline contraction coefficient & $8 \times 10^{-4}$ \\
$c_{p}$ & specific heat capacity of water & $4190 \mathrm{~J} \mathrm{~kg}^{-1} \mathrm{~K}^{-1}$ \\
$g$ & acceleration due to gravity & $9.81 \mathrm{~m} \mathrm{~s}^{-2}$ \\
$L_{\mathrm{V}}$ & latent heat of vaporisation & $2.501 \times 10^{6} \mathrm{~J} \mathrm{~kg}^{-1}$ \\
$\rho_{\mathrm{W}}$ & density of sea water & $1026 \mathrm{~kg} \mathrm{~m}^{-3}$ \\
\hline & Fixed parameters \\
\hline$c_{\mathrm{m}}$ & unsteadiness coefficient \\
$d_{\mathrm{B}}$ & scale depth of convective dissipation & $0.03 \mathrm{~m} \mathrm{~s}^{-1}(\mathrm{Kim}, 1976)$ \\
$d_{\mathrm{W}}$ & scale depth of mechanical dissipation & $10 \mathrm{~m}(\mathrm{Lemke}$ and Manley, 1984) \\
$h_{\mathrm{min}}$ & minimum mixed-layer depth & $20 \mathrm{~m}$ \\
$h_{\mathrm{S}}$ & surface (temperature) layer thickness & $10 \mathrm{~m}$ \\
\hline
\end{tabular}
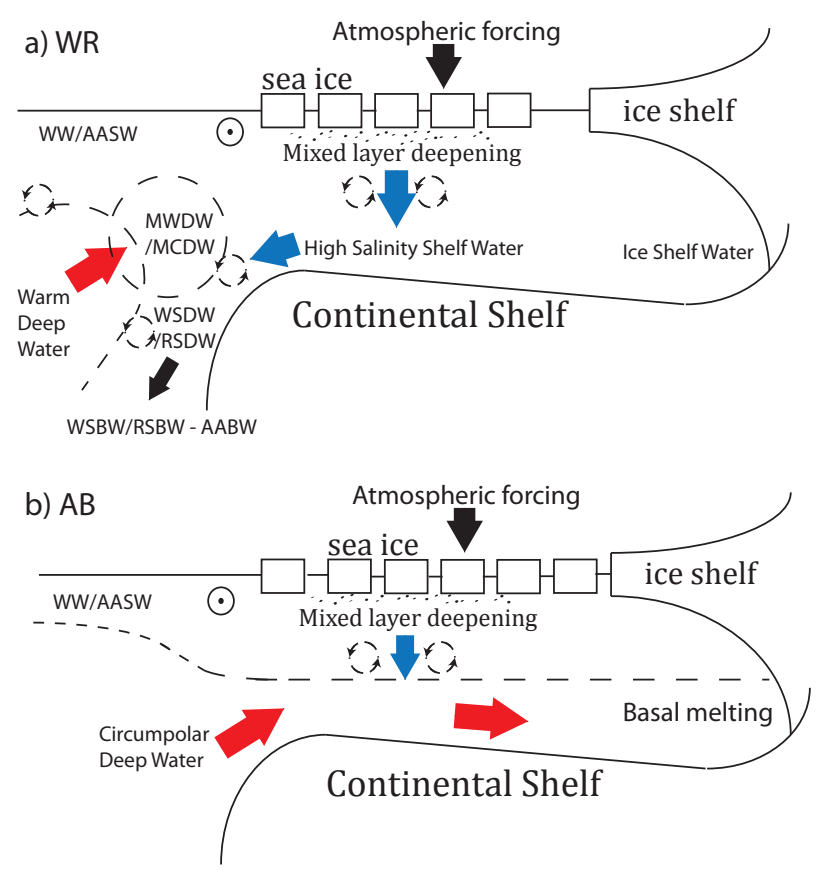

Fig. 3. Schematic of main processes in the (a) Weddell/Ross (WR) and (b) Amundsen/Bellingshausen (AB) shelf seas. AASW: Antarctic Surface Water, CDW: Circumpolar Deep Water, MCDW: Modified Circumpolar Deep Water, MWDW: Modified Warm Deep Water, RSBW: Ross Sea Bottom Water, RSDW: Ross Sea Deep Water, WDW: Warm Deep Water, WSBW: Weddell Sea Bottom Water, WSDW: Weddell Sea Deep Water, WW: Winter Water. The dotted circle indicates the westward flowing slope current.

ocean. These are all shown schematically in Fig. 4 along with several other variables described below.

We calculate an ocean heat flux from the ocean surface layer to the mixed layer as

$$
F_{\text {ocean }}=c_{p} \rho_{\mathrm{w}} u_{\star}\left(T_{\mathrm{S}}-T_{\mathrm{mix}}\right)
$$

where $c_{p}$ is the specific heat capacity of water, $\rho_{\mathrm{w}}$ is the density of sea water, $T_{\mathrm{S}}$ is the ocean surface temperature and $T_{\mathrm{mix}}$ is the mixed-layer temperature. The surface layer is assumed to be in free-drift, meaning that $u_{\star}$ is the ocean surface friction velocity, calculated through a combination of the ice-ocean wind stress $\tau_{i}$ and the open water wind stress $\tau_{o}$ as

$u_{\star}=\sqrt{\left[A\left|\tau_{i}\right|+(1-A)\left|\tau_{o}\right|\right] / \rho_{\mathrm{w}}}$.

We calculate the net salt flux (in m s${ }^{-1}$ ) into the mixed layer from the ice fraction as

$F_{\text {ice }}^{\mathrm{S}}=\left[\left(1000-S_{\text {mix }}\right) F_{\text {salt }}-S_{\text {mix }} F_{\text {fresh }}\right] A / \rho_{\mathrm{w}}$,

where $F_{\text {salt }}$ and $F_{\text {fresh }}$ are the direct fluxes of salt and freshwater respectively (in $\mathrm{kg} \mathrm{m}^{-2} \mathrm{~s}^{-1}$ ), calculated by CICE as a combination of ice/snow growth/melt and snow lost to the mixed layer through pressure ridging.

The other source of freshwater that enters the mixed layer is from precipitation and evaporation. CICE reads in both rainfall and snowfall (changing rain to snow if $T_{\mathrm{a}} \leq 0^{\circ} \mathrm{C}$ ), giving a net salt flux of

$F_{\text {pe }}^{\mathrm{S}}=-\frac{S_{\mathrm{mix}}}{\rho_{\mathrm{w}}}\left[F_{\text {rain }}+(1-A)\left(F_{\text {snow }}+F_{\text {lat }}^{\mathrm{o}} / L_{\mathrm{v}}\right)\right]$,

where $F_{\text {rain }}$ and $F_{\text {snow }}$ are the prescribed rates of rainfall and snowfall, and $L_{\mathrm{v}}$ is the latent heat of vaporisation. Note that rainfall on sea ice is assumed to percolate through the sea ice and enters the mixed layer.

\subsubsection{Power input}

The mixed layer is provided with mechanical energy to deepen through both convective mixing driven by surface buoyancy fluxes (where the gravitational potential energy is converted into kinetic energy within the mixed layer) and directly through wind mixing. 


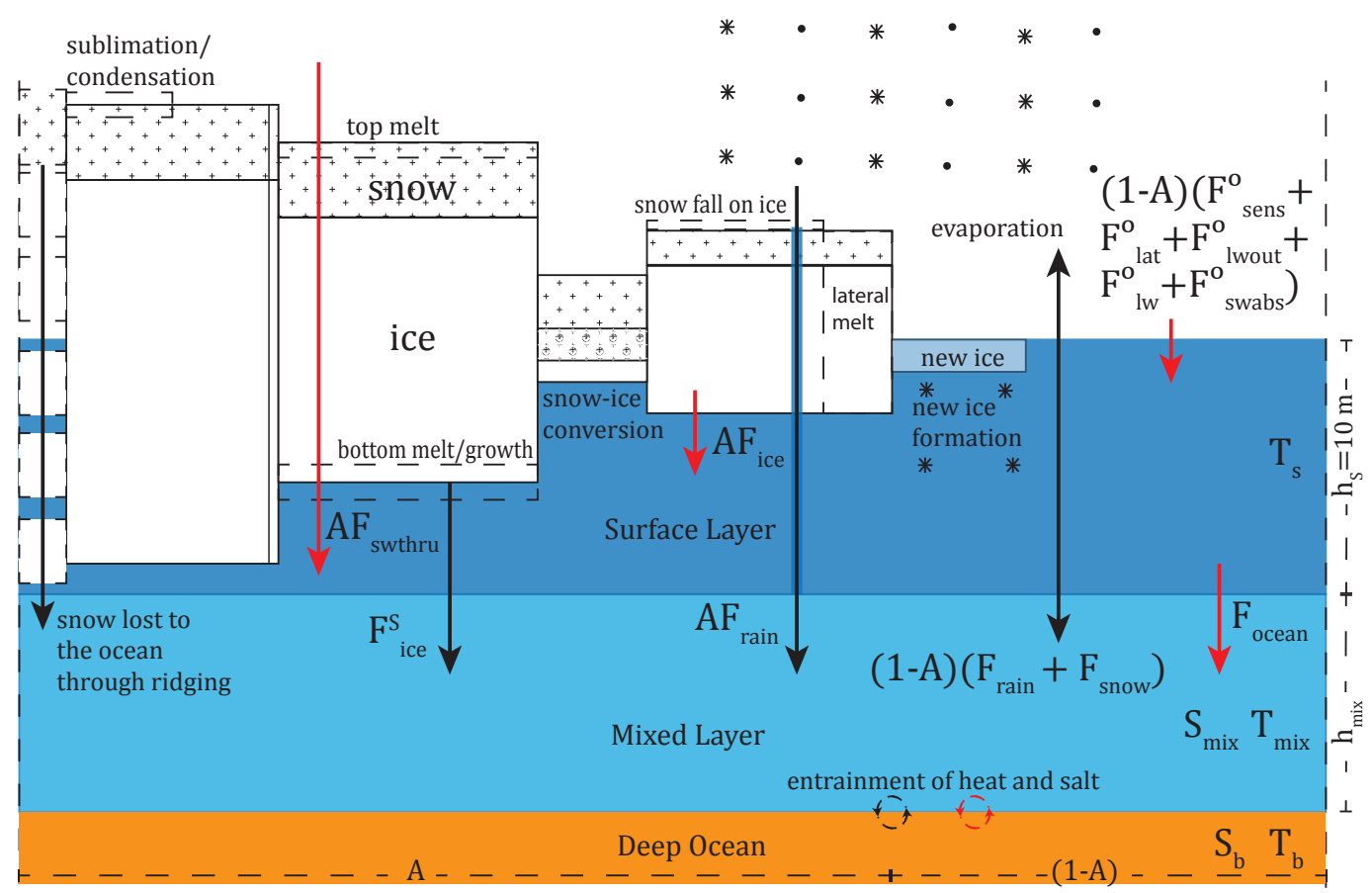

Fig. 4. Schematic of the main thermodynamic processes included in CICE. $A$ : total ice concentration within the grid cell, $F_{\text {lat }}^{\mathrm{o}}:$ latent heat flux over the open water fraction, $F_{\text {lwin }}^{\mathrm{o}}$ : downward long-wave radiative heat flux into the open water fraction, $F_{\text {lwout }}^{\mathrm{o}}$ : black-body radiative heat flux from the open water fraction, $F_{\text {ice }}$ : conductive heat flux through the ice, $F_{\text {ice }}^{\mathrm{S}}$ : net salt flux from ice/snow growth/melt, $F_{\text {rain }}$ : rainfall over the grid cell, $F_{\text {ocean }}$ : ocean-surface mixed-layer heat flux, $F_{\text {sens }}^{\mathrm{o}}$ : sensible heat flux over the open water fraction, $F_{\text {snow }}$ snowfall over the grid cell, $F_{\text {swabs }}^{\mathrm{o}}$ : short-wave radiative heat flux absorbed by the open water fraction, $F_{\text {swthru }}$ : short-wave radiative heat flux through the ice, $S_{\mathrm{B}}$ : salinity directly below the mixed layer, $S_{\mathrm{mix}}$ : mixed-layer salinity, $T_{\mathrm{B}}$ : temperature directly below the mixed layer, $T_{\mathrm{S}}$ : surface layer temperature, $T_{\mathrm{mix}}$ : mixed-layer temperature. Red arrows indicate heat fluxes while black arrows indicate salt/freshwater fluxes.

The rate of mechanical energy input to the mixed layer from surface buoyancy fluxes is given by a combination of the following: (i) salt/freshwater flux from sea ice growth/melt $P_{\text {salt }}$; (ii) salt/freshwater flux from precipitation and evaporation $P_{\mathrm{pe}}$; (iii) the heat flux between the ocean surface layer and the mixed layer $P_{\text {heat }}$; and (iv) wind shearing from the ice and open water fractions $P_{\text {wind }}$. By splitting up the relative contributions to the surface power input we can analyse the impact of each term on the mixed-layer evolution. The surface power inputs (per unit density, i.e. in $\mathrm{m}^{3} \mathrm{~s}^{-3}$ ) from surface buoyancy fluxes are given respectively as

$$
\begin{aligned}
& P_{\text {salt }}=c_{\mathrm{B}} g \beta h_{\text {mix }} F_{\text {ice }}^{\mathrm{S}}, \\
& P_{\mathrm{pe}}=c_{\mathrm{B}} g \beta h_{\text {mix }} F_{\mathrm{pe}}^{\mathrm{S}}, \\
& P_{\text {heat }}=-\frac{c_{\mathrm{B}} g \alpha h_{\mathrm{mix}}}{c_{p} \rho_{\mathrm{w}}} F_{\text {ocean }},
\end{aligned}
$$

where $\alpha$ is a thermal expansion coefficient, $\beta$ is a saline contraction coefficient, $g$ is the acceleration due to gravity, $h_{\text {mix }}$ is the mixed-layer depth and

$c_{\mathrm{B}}=\exp \left(-h_{\text {mix }} / d_{\mathrm{B}}\right)$ is a variable parameter describing the fraction of energy that remains in the mixed layer after convective dissipative effects are taken into account, where $d_{\mathrm{B}}$ is a scale depth of convective dissipation. Note that to allow for the representation of deep (several hundred metres deep) mixed layers we place a limit on dissipation, such that $c_{\mathrm{B}} \geq \exp \left(-h_{\mathrm{B}}^{\max } / d_{\mathrm{B}}\right)$ following Lemke et al. (1990). We have used a value of $h_{\mathrm{B}}^{\max }=100 \mathrm{~m}$ instead of the Lemke et al. (1990) value of $50 \mathrm{~m}$ to increase the potential dissipation of energy within the mixed layer. This reduces deep convection and prevents a large polynya that forms every winter in the Weddell Sea near the Greenwich Meridian. This is a region of observed low ice concentrations (Lindsay et al., 2004) which is due to a halo of warm waters encircling the Maud Rise at depths just below the mixed layer (de Steur et al., 2007), a process that is impossible to capture in our simple model.

The input of power from wind shearing is

$$
P_{\text {wind }}=c_{\mathrm{w}} u_{\star}^{3} \text {, }
$$

where $c_{\mathrm{W}}$ is a depth-dependent dissipation coefficient for wind mixing, given by

$c_{\mathrm{w}}=\exp \left(-h_{\operatorname{mix}} / d_{\mathrm{w}}\right)$ 
where $d_{\mathrm{w}}$ is a scale depth of mechanical dissipation. We define the net power input $P_{\text {net }}$ as the sum of the four surface power input terms described above. We also later discuss the annual time integrals of these power input terms to analyse the net annual (mechanical) energy input to the mixed layer, referred to as $W_{\text {salt }}, W_{\text {pe }}, W_{\text {heat }}, W_{\text {wind }}, W_{\text {net }}$ (not density weighted, so in units of $\mathrm{J} \mathrm{m}^{-2}$ ).

\subsubsection{Mixed-layer entrainment}

We use the zero-dimensional bulk mixed-layer energy balance formulation of Kraus and Turner (1967) and Niiler and Kraus (1977), which assumes that temperature and salinity are uniform throughout the mixed layer, and there is a full balance in the sources and sinks of turbulent kinetic energy (TKE) (see Petty et al. (2012) for further details about this model choice). While our precise definition of $h_{\text {mix }}$ varies for salinity and temperature due to the surface temperature layer, we believe that the error this introduces to the energy balance will have an insignificant impact on the results compared to the general assumptions made by the bulk mixedlayer model. The mixed-layer entrainment rate is calculated by balancing the energy needed to entrain water from below with the energy provided by the wind and the surface buoyancy fluxes which, when rearranged, gives the mixed-layer entrainment rate as

$w=\frac{\mathrm{d} h_{\text {mix }}}{\mathrm{d} t}=\frac{P_{\text {net }}}{h_{\text {mix }} \Delta b+c_{\mathrm{m}}^{2}}$,

where $c_{\mathrm{m}}$ is a bulk turbulent velocity scale representing the turbulent fluctuations of the mixed layer that will result in a frictional sink of TKE, and $\Delta b$ is the difference in the buoyancy of the waters across the mixed-layer base, given by

$\Delta b=g \alpha\left(T_{\mathrm{mix}}-T_{\mathrm{B}}\right)-g \beta\left(S_{\mathrm{mix}}-S_{\mathrm{B}}\right)$,

where $T_{\mathrm{B}}$ and $S_{\mathrm{B}}$ are the deep ocean temperature and salinity respectively, which are both prognostic variables in this model (see Sect. 2.1.5).

This entrainment rate calculation is also used when $w<0$ to force the mixed layer to detrain back to a stable depth. We use a minimum mixed-layer depth such that $h_{\text {mix }} \geq h_{\text {min }}$. During detrainment the salinity and temperature is only updated through surface fluxes, leaving behind a layer of Winter Water. If the calculated mixed-layer depth is greater than the seabed depth $h_{\text {bath }}$ the entrainment rate is reduced such that the mixed-layer depth equals the respective limit.

\subsubsection{Temperature and salinity calculations}

Through a combination of surface and entrainment heat/salt fluxes we calculate the changes in the mixed-layer tempera- ture and salinity as

$$
\begin{aligned}
& \frac{\mathrm{d} T_{\text {mix }}}{\mathrm{d} T}= \begin{cases}\frac{F_{\text {ocean }}}{\rho_{\mathrm{w}} c_{p} h_{\text {mix }}}+\frac{w}{h_{\text {mix }}}\left(T_{\mathrm{B}}-T_{\text {mix }}\right) & w>0 \\
\frac{F_{\text {ocean }}}{\rho_{\mathrm{w}} c_{p} h_{\text {mix }}} & w \leq 0,\end{cases} \\
& \frac{\mathrm{d} S_{\text {mix }}}{\mathrm{d} T}= \begin{cases}\frac{F_{\text {ice }}^{\mathrm{S}}+F_{\mathrm{pe}}^{\mathrm{S}}}{h_{\text {mix }}}+\frac{w}{h_{\text {mix }}}\left(S_{\mathrm{B}}-S_{\text {mix }}\right) & \text { for } w>0 \\
\frac{F_{\text {ice }}^{\mathrm{S}}+F_{\mathrm{pe}}^{\mathrm{S}}}{h_{\text {mix }}} & \text { for } w \leq 0,\end{cases}
\end{aligned}
$$

and an ocean surface temperature change given by

$\frac{\mathrm{d} T_{\mathrm{S}}}{\mathrm{d} T}=\frac{F_{\text {surface }}-F_{\text {ocean }}}{c_{p} \rho_{\mathrm{w}} h_{\mathrm{S}}}$.

We compute the potential to freeze/melt ice in the surface layer as

$H_{\text {frzmlt }}^{\mathrm{S}}=c_{p} \rho_{w} h_{\mathrm{S}}\left(T_{\mathrm{f}}-T_{\mathrm{S}}\right) / \mathrm{d} T$,

where $T_{\mathrm{f}}=273.15-0.054 S_{\text {mix }}$ is the calculated freezing temperature for seawater at the surface. We ensure $T_{\mathrm{S}} \geq T_{\mathrm{f}}$, such that any latent heat flux from ice formation is included in the heat flux calculations. In the case that $T_{\operatorname{mix}}<T_{\mathrm{f}}$ we compute the potential to form ice in the mixed layer (not melting as it is separated from the ice by the surface layer) as

$H_{\text {frzmlt }}^{\operatorname{mix}}=c_{p} \rho_{w} h_{\text {mix }}\left(T_{\mathrm{f}}-T_{\text {mix }}\right) / \mathrm{d} T$ for $T_{\text {mix }}<T_{\mathrm{f}}$

in which case we set $T_{\text {mix }}=T_{\mathrm{f}}$ to ensure $T_{\mathrm{mix}} \geq T_{\mathrm{f}} . H_{\mathrm{frzm}}^{\operatorname{mix}}+$ $H_{\text {frzmlt }}^{S}$ is then returned to CICE as the net potential to grow/melt ice.

\subsubsection{Representation of the deep ocean}

We use a 3-D grid to represent the deep ocean, with the deepocean column at each horizontal $(x, y)$ grid cell given by

$T_{\text {ocean }}=\left\{T\left(z_{1}\right), T\left(z_{2}\right), T\left(z_{3}\right), \ldots, T\left(z_{N}\right)\right\}$
$S_{\text {ocean }}=\left\{S\left(z_{1}\right), S\left(z_{2}\right), S\left(z_{3}\right), \ldots, S\left(z_{N}\right)\right\}$

where $z$ represents the vertical ocean grid index and $N$ is the number of vertical levels chosen. At every time step we assign the mixed-layer temperature and salinity to the deep ocean grid within the mixed layer. The signature of Winter Water is therefore retained in the deep ocean as the mixed layer retreats back to a shallower depth. The precise depth levels and $T / S$ data used are described in Sect. 2.2.

The ocean grid is used to determine the temperature and salinity of the waters entrained into the mixed layer, using a linear interpolation scheme to update the values of $S_{\mathrm{B}}$ and $T_{\mathrm{B}}$ to account for the coarse ocean grid. In the case of a very 


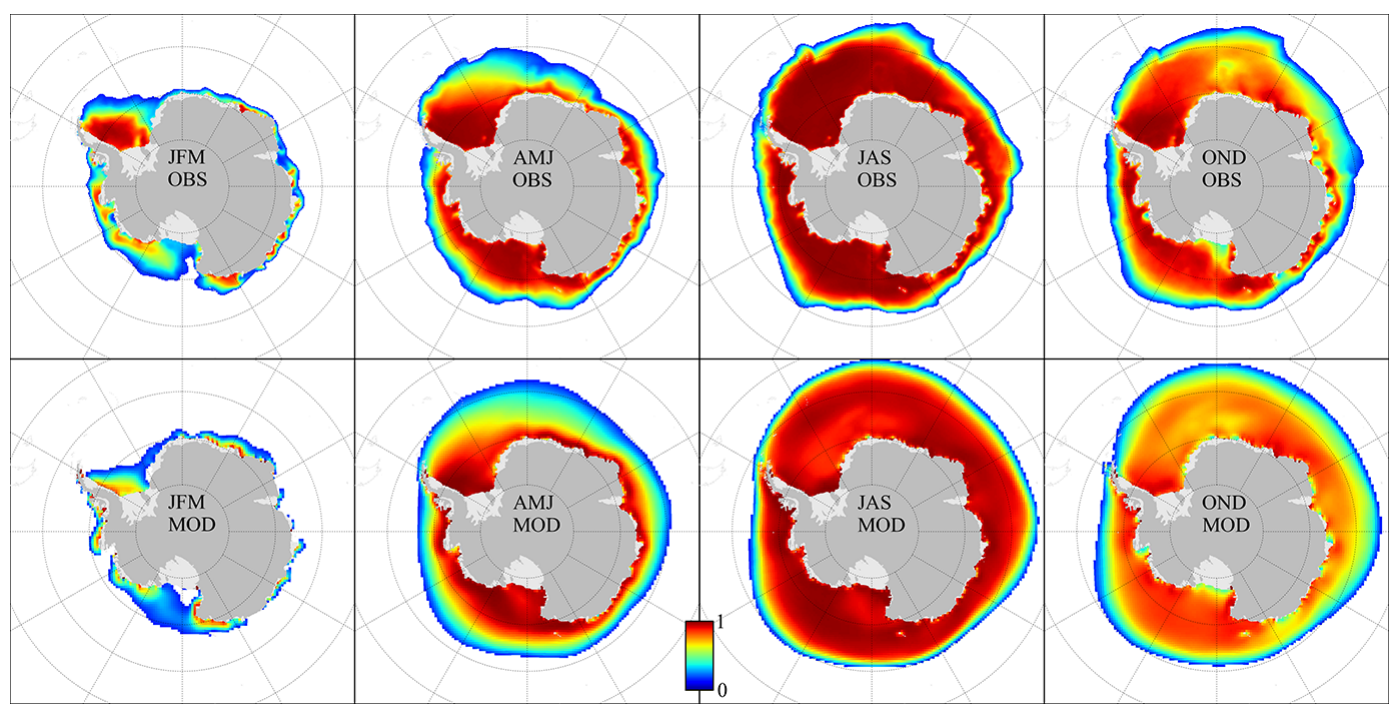

Fig. 5. Mean (1985-2011) seasonal observed (top row) and modelled (bottom row) ice concentration. Ice concentration observations calculated using the Bootstrap algorithm (Comiso, 1999). Ice concentrations less than 0.15 are masked in both data sets. JFM: January-March (summer), AMJ: April-June (autumn), JAS: July-September (winter), OND: October-December (spring).

shallow or deep mixed layer we simply set $T_{\mathrm{B}}$ and $S_{\mathrm{B}}$ to top or bottom values. The $T / S$ values for depth levels deeper than the mixed layer at any given time are slowly relaxed back to their initial values to loosely represent ocean dynamics restoring the Winter Water back towards the mean (summertime) ocean conditions. We use a restoration timescale of $R_{\mathrm{T}}=3$ months as we expect this restoration to take place predominantly through spring.

\subsubsection{Ice dynamics}

Since we force the model with near-surface wind speeds, the effect of the turning angle within the atmospheric Ekman layer has been accounted for. However, Kimura (2004) shows the angle between surface winds and ice motion to be around $10-20^{\circ}$, which is a mainly result of the ocean Ekman layer. The ice-ocean drag is given by

$\boldsymbol{\tau}_{\boldsymbol{i}}=c_{\mathrm{d}} \rho_{\mathrm{w}}\left|\boldsymbol{U}_{\mathrm{w}}-\boldsymbol{u}\right|\left[\left(\boldsymbol{U}_{\mathrm{w}}-\boldsymbol{u}\right) \cos \theta_{\mathrm{w}}+\boldsymbol{k} \times\left(\boldsymbol{U}_{\mathrm{w}}-\boldsymbol{u}\right) \sin \theta_{\mathrm{w}}\right]$

where $\boldsymbol{u}$ is the ice velocity, $\boldsymbol{U}_{\mathrm{w}}$ is the geostrophic ocean velocity (ocean currents are neglected here meaning $\boldsymbol{U}_{\mathrm{w}}=0$ ), $c_{\mathrm{d}}$ is an ice-ocean drag coefficient, and $\theta_{\mathrm{w}}\left(=-15^{\circ}\right.$ in this study) is the ocean turning angle (negative for the Southern Ocean) between the geostrophic ocean currents and the ocean surface currents under the ice.

\subsection{CICE configuration}

We have configured CICE to run in stand-alone mode on a $0.5^{\circ}$ rotated lat/long grid $(176 \times 176)$ with the north pole at the equator (i.e. horizontal resolution of around $55 \mathrm{~km}$ ). An Antarctic land mask and bathymetry are produced through an interpolation of the RTOPO data set (Timmermann et al.,
2010). Atmospheric forcing data are taken from the ERAInterim reanalysis (Dee et al., 2011) and consist of 6-hourly fields of $10 \mathrm{~m}$ zonal and meridional winds, $2 \mathrm{~m}$ air temperature and specific humidity, daily fields of downward shortwave and long-wave radiation and monthly fields of precipitation (snow and rain). Mean (1980-2011) winter ERAInterim forcing data are shown in Fig. 2.

The idealised modelling study of Petty et al. (2012) demonstrated that regional atmospheric differences are sufficient in explaining the potential formation of deep mixed layers. However, a realistic deep ocean was shown to be important in simulating a realistic sea ice and mixed-layer cycle. We choose to satisfy this requirement by initialising and restoring the 3-D ocean grid (described in Sect. 2.1.5) towards a realistic 3-D "climatological" deep ocean, based on World Ocean Atlas 09 (WOA09) data.

We use WOA09 temperature (Antonov et al., 2010) and salinity (Locarnini et al., 2010) data, which consist of climatological fields of in situ data interpolated to standard depth levels on a $1^{\circ}$ grid. The annual climatology data have been interpolated onto the CICE grid described above, with a weighted extrapolation procedure used to fill any missing grid points found near the coastline, and smoothed using a nine-point Gaussian filter. We use a coarse vertical grid to represent the deep ocean, with depth values corresponding to $z=(30,50,100,150,200,300,400,600,800,1000) \mathrm{m}$ levels. The WOA09 data at each of these $z$ levels is initialised in our $T, S$ deep ocean grids at each grid point and $S_{\text {mix }}, T_{\text {mix }}$ and $T_{\mathrm{S}}$ are initialised to the $z=30 \mathrm{~m}$ values. The mixed-layer salinity is restored back to the annual climatological $(30 \mathrm{~m})$ value with a period of 1 year. This is introduced to balance 
any loss of salt from deep ocean relaxation and simplistically represents the export of mixed-layer waters off the shelf.

Ice and snow thicknesses are initialised at $\sim 1.5 \mathrm{~m}$ and $\sim 0.2 \mathrm{~m}$ respectively in the grid cells where the surface temperature is below freezing. We start the model in March when sea ice at its lowest extent (Comiso, 1999) and is approximately the date on which the majority of WOA09 Antarctic shelf sea measurements have been taken (due to this sea ice minimum). The model is spun up for 5 years (19801984), before producing our analysis simulation for 27 years (1985-2011).

\section{Model results}

\subsection{Modelled sea ice state}

As we are modelling the impact of the atmosphere on the shelf seas, it is important we achieve an accurate sea ice state to validate the fluxes of freshwater, salt, heat and momentum between the atmosphere and the ocean. Figure 5 shows a comparison of the mean (seasonal) modelled ice concentration compared to observations derived from passive microwave emissions using the Bootstrap algorithm (Comiso, 1999). The model simulates reasonably well the seasonal sea ice cycle, with the best fit to data in autumn (April, May, June), when the mixed-layer depth has the highest growth rates. There is, however, an overestimation of the seasonal cycle, with the ice extent too high in winter and too low in summer. The maximum wintertime ice extent is unlikely to be of much importance for our study as we are focused on the impact of sea ice on the southern shelf seas, well away from the wintertime sea ice edge. However, the low summer ice concentration is a concern as this extra ice melt will probably over-stratify the shelf seas in summer and affect the subsequent autumn ice growth. In the Weddell Sea, the modelled low ice concentration in summer appears to be linked to low ice concentrations in winter and spring, while in the Amundsen Sea embayment, a polynya forms in spring leading to an ice-free region in summer. The Ross and Bellingshausen seas appear to have the best fit to observations.

Figure 6 shows the mean (seasonal) modelled ice motion. In most regions, the ice follows the pattern of the nearsurface winds, with a slight leftward deflection due to the ocean turning angle, consistent with weak or negligible internal ice stresses. There is a strong northward ice motion in the Ross and westward coastal current in East Antarctica as we would expect from both the near-surface winds (Fig. 2a) and by comparing to ice motion derived from passive microwave feature-tracking (Holland and Kwok, 2012).

Figure 7 shows the mean (seasonal) modelled ice thickness compared to observations of ice thickness from the 2003-2008 ICESat laser altimetry freeboard measurements (Kurtz and Markus, 2012), which assumes that the ice-snow interface is at sea level, i.e. that all freeboard is snow and

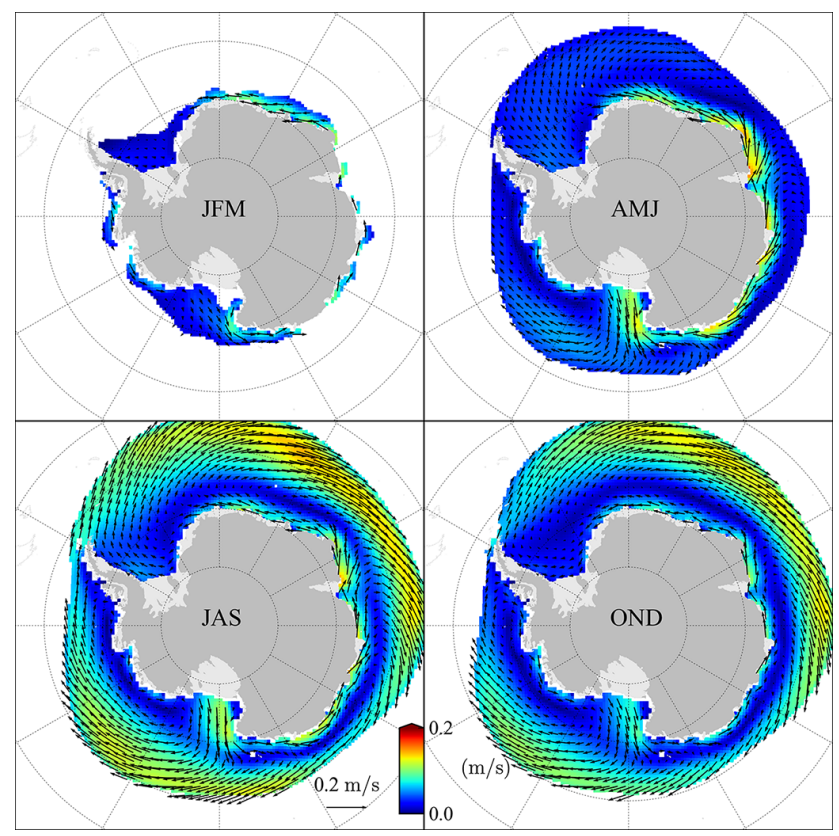

Fig. 6. Mean (1985-2011) seasonal modelled ice motion (ice speed overlain with ice motion vectors). Regions corresponding to a mean ice concentration less than 0.15 are masked in both data sets. JFM: January-March (summer), AMJ: April-June (autumn), JAS: JulySeptember (winter), OND: October-December (spring).

all draft is solid ice. The modelled results agree well in the general location of regions of thicker and thinner ice, although the absolute values of ice thickness show differences across all seasons and regions. The modelled Weddell Sea ice thickness shows the best fit to observations throughout the year, especially in spring. The model shows a perennially thicker $(\sim 1 \mathrm{~m})$ sea ice cover in the Bellingshausen Sea which will result in lower growth and melt rates and could also prevent the advection of ice into the Amundsen Sea embayment, where the modelled ice thickness remains very low throughout the year. The model shows perennially thin ice in the Ross Sea, however in spring this is only over the southern half of the shelf sea whereas the observations suggest it could cover a much higher fraction of the shelf sea area.

\subsection{Modelled mixed layer}

Figure 8a shows the mean (1985-2011) maximum mixedlayer depth (MLD) in each grid cell, demonstrating the ability of this simple mixed layer model to produce the expected regional distribution of maximum MLD over the Antarctic continental shelf. The MLD maximum (which mostly occurs in winter) is deepest in the Weddell and Ross seas, with the black crosses highlighting grid cells where the maximum MLD is greater than $90 \%$ of the water column depth. To further highlight this destratification, Fig. $8 \mathrm{~b}$ shows the fraction of the water column occupied by the maximum MLD. Figure $8 \mathrm{c}$ shows the mean annual ice growth (calculated by 


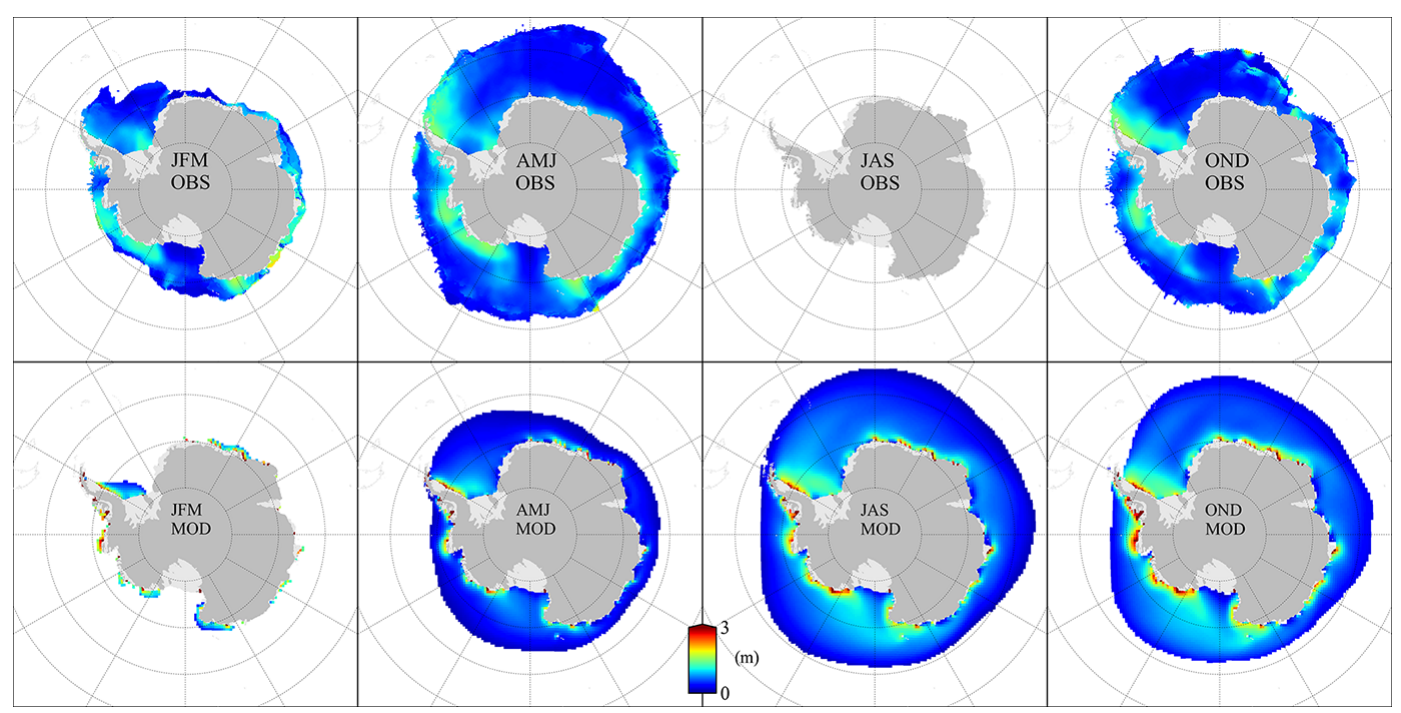

Fig. 7. Mean (1985-2011) seasonal modelled ice thickness (bottom row) compared to mean (2003-2008) seasonal observed ice thickness (top row). Ice thickness observations taken from ICESat measurements (Kurtz and Markus, 2012). Note that no observations were obtained during winter (JAS). Regions with a respective ice concentration less than 0.5 are masked in both data sets. JFM: January-March (summer), AMJ: April-June (autumn), JAS: July-September (winter), OND: October-December (spring).

summing together all positive months of ice growth (per unit area) within each grid cell), demonstrating a clear relationship between high ice production and deep mixed layers. Figures 9 and 10 show the bottom salinity and temperature, respectively, at the end of summer (March), and the difference between the end of winter (October) and summer bottom salinity and temperature, in the Weddell and Ross shelf seas. The end of summer salinity/temperature fields in Figs. 9 and 10 show effectively WOA09 data, due to the relatively rapid ( 3 month) relaxation time period, while the difference between winter and summer fields show the impact from grid cells that have destratified the water column.

In the Weddell Sea, the summertime bottom salinity/temperature in Figs. 9a and 10a show relatively cold $\left(\sim-1.6^{\circ} \mathrm{C}\right)$ and high-salinity $(\sim 34.8)$ waters in the southwest corner of the shelf, relatively cold $\left(\sim-1.6^{\circ} \mathrm{C}\right)$ but fresher ( 34.5-34.6) waters over the Berkner Bank in the centre of the shelf, and near-freezing $\left(\sim-1.9^{\circ} \mathrm{C}\right)$ saline $(\sim 34.7)$ waters in the Filchner Depression. This compares reasonably well with the summertime measurements of Nicholls et al. (2003). East of the Filchner Depression along the Luitpold Coast, the water mass properties are similar to that over the Berkner Bank, with slightly fresher ( 34.5) waters to the north, near the Brunt Ice Shelf. This water mass is often classified as eastern shelf water (ESW) where the water column is thought to be freshened by the presence of ice shelf water in the region (Fahrbach et al., 1994). The observations of Nicholls et al. (2009) and Årthun et al. (2012) suggest a reasonable fit with temperature but salinities that are slightly higher (by around 0.1-0.2) compared to observations.
In winter, Figs. 8a, 9c and 10c show a complete destratification along the Ronne Ice Front, over the shallow $(\sim 300 \mathrm{~m})$ Berkner Bank and along the Luitpold Coast up to the Brunt Ice Shelf. In many of the grid cells along the ice front, the water column remains around freezing throughout the year meaning that not much of a temperature change is observed, whereas in other regions, such as over the Berkner Bank and along the Luitpold Coast, the water column has cooled significantly (by $\sim-0.6^{\circ} \mathrm{C}$ ) due to destratification cooling the warmer summertime waters to near-freezing. In winter, complete destratification along the Ronne Ice Front causes the bottom salinity to increase by $\sim 0.2$ (from $\sim 34.7$ to $\sim 34.9$ ) in a few grid cells, due to the more rapid sea ice production (discussed in more detail in Sect. 3.4.1). The large region of destratification over the shallow Berkner Bank, in contrast, results in a slight freshening $(<0.1)$ of the waters at the seabed. The destratification and bottom salinity/temperature compares well with the wintertime observations of this region (Nicholls et al., 2008). The results also fit well with the idea discussed by Nicholls et al. (2009), that MWDW is cooled over much of the shelf, with the resultant water mass mixing with more saline waters formed close to the Ronne Ice Front to give the signature HSSW that is eventually advected off the shelf. The complete destratification along the Luitpold Coast has also been observed in recent seal-tag CTD measurements (Årthun et al., 2012), which, in agreement with the model, show a destratified yet low-salinity $(\sim 34.4)$ water column, with the bottom salinity fresher in winter compared to summer. In both this and the Berkner Bank destratification, it is thought that the destratifying potential is insufficient to cause further salination once 


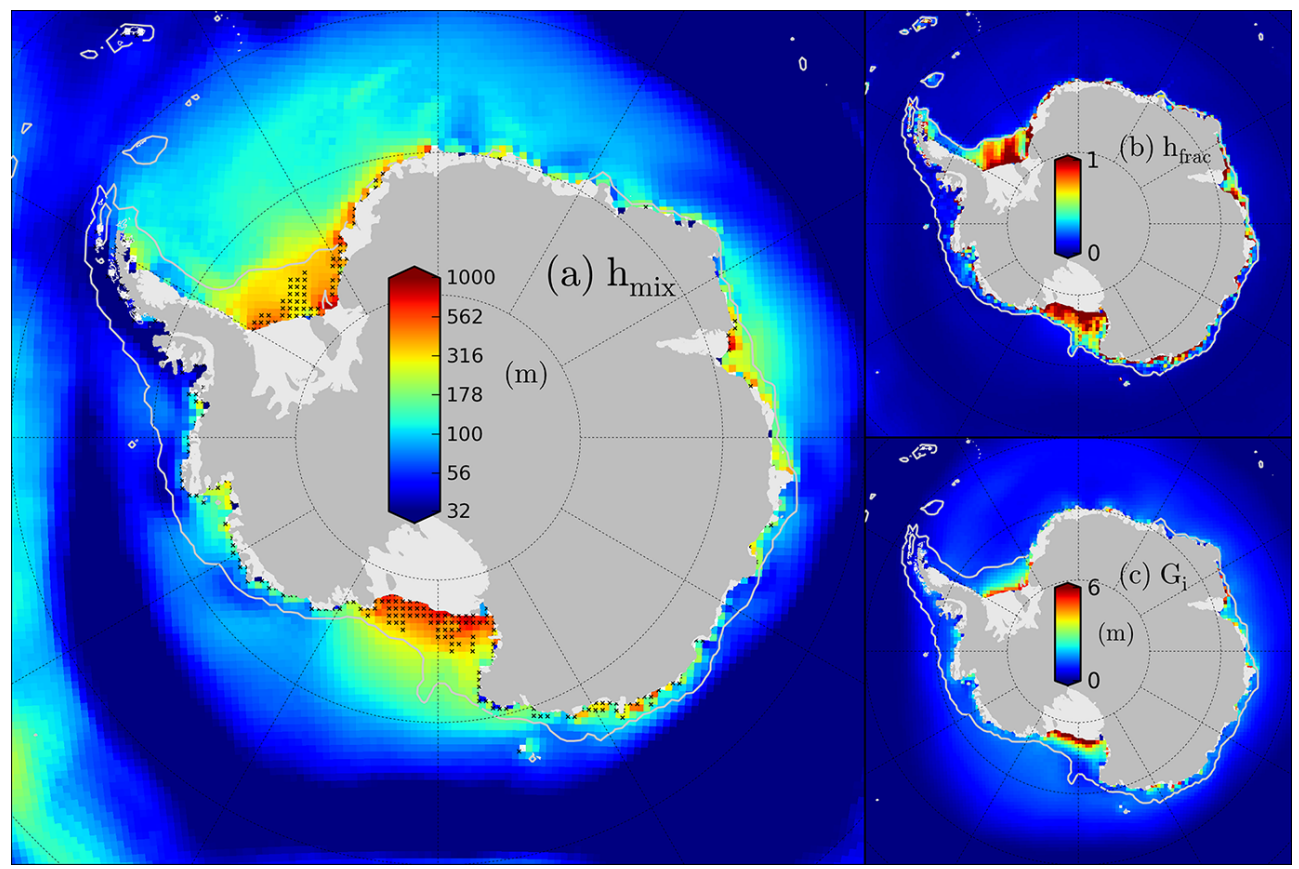

Fig. 8. Mean (1985-2011) (a) maximum mixed-layer depth, (b) fractional depth of (a) as a function of the water column depth and (c) annual ice growth. Note that a logarithmic (base 10) colour bar/scale is used in panel (a). The black crosses highlight grid cells where the maximum mixed-layer depth is greater than $90 \%$ of the water column depth. The white line is the $1000 \mathrm{~m}$ isobath contour taken from the RTOPO data set (Timmermann et al., 2010).

the water column is well mixed, as opposed to the more rapid mixing taking place along the Ronne Ice Front.

In the Ross Sea, the summertime bottom salinity/temperature in Figs. $9 \mathrm{~b}$ and $10 \mathrm{~b}$ show near-freezing $\left(\sim-1.9^{\circ} \mathrm{C}\right) \mathrm{HSSW}(\sim 34.7-34.8)$ in the southwest corner of the shelf, and slightly warmer $\left(\sim-1.6^{\circ} \mathrm{C}\right)$ and fresher $(\sim 34.5)$ waters in the eastern corner of the shelf. This is a similar regional pattern to the Weddell shelf and matches well the summertime observations, as summarised by Orsi and Wiederwohl (2009).

In winter, Figs. $8 \mathrm{a}, 9 \mathrm{~d}$ and $10 \mathrm{~d}$ show a complete destratification over much of the southern Ross shelf. The water column destratifies along much of the Ross Ice Front and towards the centre of the shelf, also in regions with a shallow water column. Similar to the Weddell Sea, there are only a few regions in which the bottom salinity increases from its summertime value, despite the large region of destratification, with the deep (800-1000 m) water column appearing to limit the potential salinity increase compared to the Weddell Sea. In the eastern Ross shelf, the destratification causes a freshening $(\sim 0.1)$ at the seabed, similar to the Berkner Bank in the Weddell Sea, as discussed earlier.

Figure 8 shows that the winter maximum mixed layer remains very shallow $(<100 \mathrm{~m})$ in the Bellingshausen Sea, with the deepest (200-300 m) mixed layers found in a small coastal region of Eltanin Bay, where the observations of Tamura et al. (2008) show polynya formation. Deep con- vection from winter polynyas in Eltanin Bay is discussed in the modelling study of Holland et al. (2010). Observations of winter mixed layers from thermistor moorings between 2007 and 2010 (Martinson and McKee, 2012) show a mixed layer extending down to around $100-150 \mathrm{~m}$ every winter in the Marguerite Bay, while Meredith et al. (2010) find shallower mixed layers further inshore. Observations of the Winter Water depth in summer (Martinson et al., 2008; Jenkins and Jacobs, 2008) show that maximum mixed-layer depths are $100-200 \mathrm{~m}$ over a much wider area.

The Amundsen Sea in general has deeper maximum mixed layers in winter than the Bellingshausen Sea, with mixed layers in the embayment reaching depths of around 200 $300 \mathrm{~m}$ and the majority of the remaining shelf sea showing mixed layers reaching depths of 100-200 m. To our knowledge, there are no wintertime oceanographic sections from this region, but summertime observations of Winter Water depth suggest that the mixed-layer depth in the embayment, and the deepening tendency towards the coast, are accurate (Jacobs et al., 2011, 2012). However, modelled mixed-layer depths near the shelf break are too shallow, and a deepening to the west (Jacobs et al., 2012) is not captured. These features are probably driven by Ekman convergence, which is neglected here. 

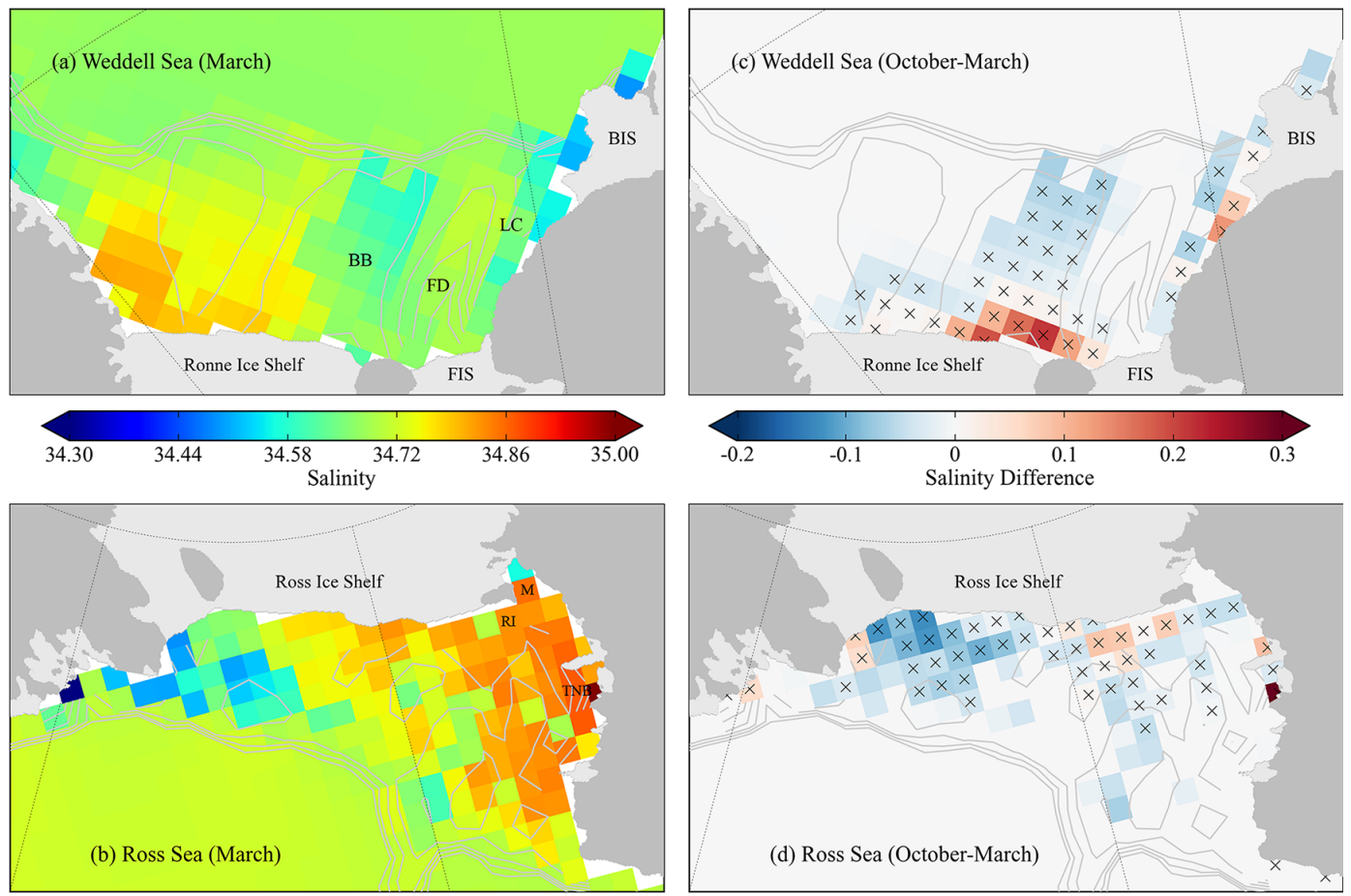

Fig. 9. Mean (1985-2011) modelled bottom salinity in summer (March) of the (a) Weddell and (b) Ross shelf seas, and the difference between the winter (October) and summer (March) bottom salinity of the (c) Weddell and (d) Ross shelf seas. The crosses highlight grid cells where the mean maximum mixed-layer depth is greater than $90 \%$ of the water column depth. BB: Berkner Bank, FD: Filchner Depression, FIS: Filchner Ice Shelf, RIS: Ronne Ice Shelf, BIS: Brunt Ice Shelf, LC: Luitpold Coast, RI: Ross Island, RIS: Ross Ice Shelf, M: McMurdo Sound, TNB: Terra Nova Bay. Note that the deep ocean grid is capped at a depth of $1000 \mathrm{~m}$, meaning that the water north of the shelf break reflects the WOA09 data at this depth. The grey lines are isobaths spaced at $200 \mathrm{~m}$ intervals up to $1000 \mathrm{~m}$.
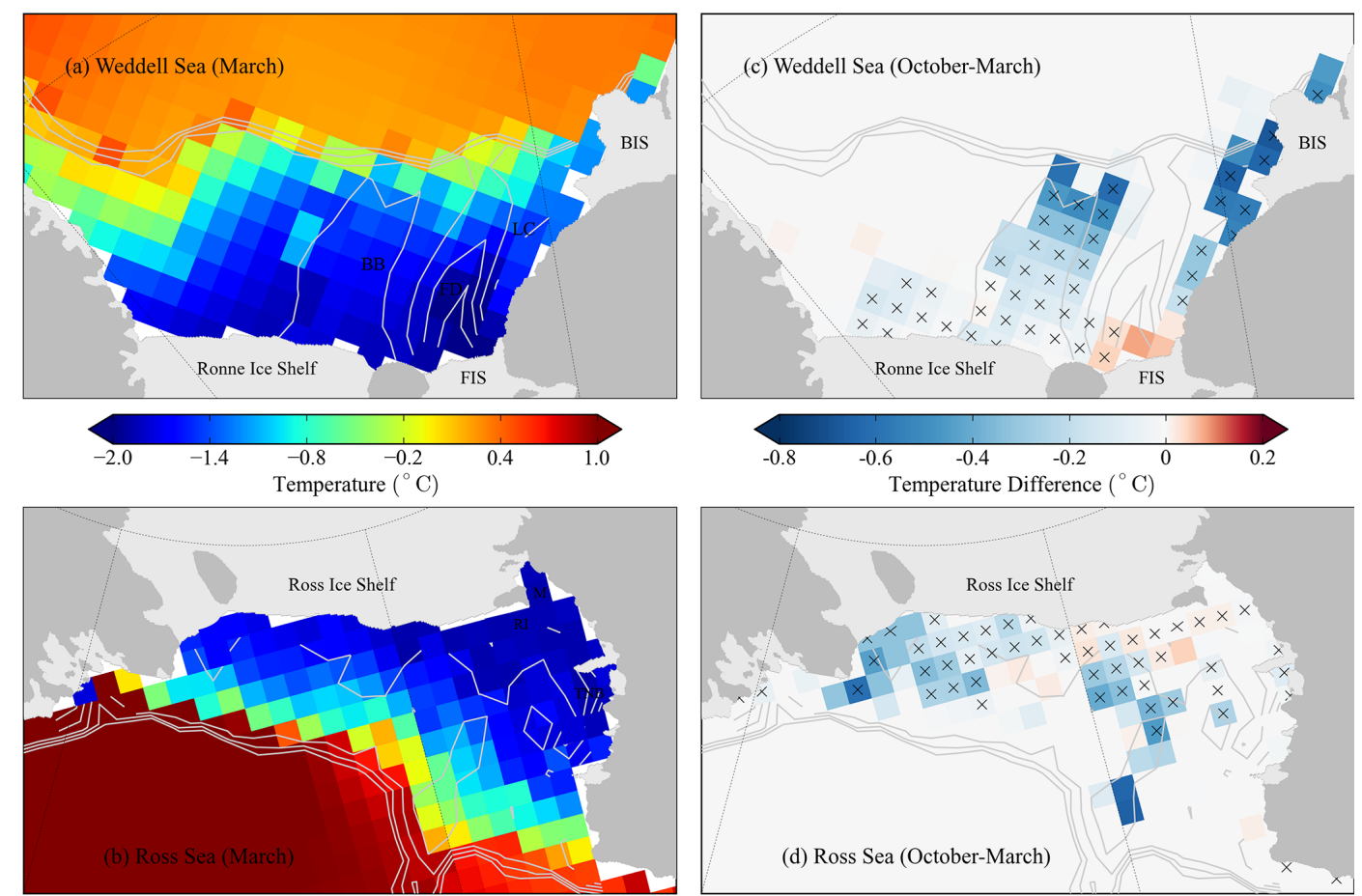

Fig. 10. As in Fig. 9 but for bottom temperature. 


\subsection{Analysis of the mixed-layer evolution}

To understand in more detail the causes of the mixed-layer evolution, Fig. 11a-d show the long-term mean (1985-2011) deconstructed input of mechanical power from the ocean surface to the mixed layer as described in Sect. 2.1.2. Note that these terms are the fraction of power remaining after dissipative effects are taken into account (during deepening only). The evolution of the mean mixed layer depth over the study regions is also shown to demonstrate how this surface power input drives the mixed-layer evolution. Figure 11 shows that in all four regions the net power input closely follows the power input from the net salt flux due to ice growth and melt. There is a small contribution from the heat flux term, with wind mixing and precipitation minus evaporation providing a negligible impact.

Figure 11e shows the mean (1985-2011) net surface power input annual cycle for all four regions, highlighting the extremely low autumn/winter mixed-layer power input to the Amundsen and Bellingshausen seas compared to the Weddell and Ross seas. This result demonstrates that the deep mixed layers that form in the Weddell and Ross seas can potentially be attributed simply to a greater input of power at the surface in autumn/winter, providing further evidence to support the hypothesis of Talbot (1988) and Petty et al. (2012) that regionally varying ocean surface fluxes are sufficient in explaining the bimodal distribution in the shelf seabed temperature. However, the simplicity of our model means that we are not able to rule out a competing contribution to this distribution from regionally varying ocean dynamics (e.g. ocean stratification or deep ocean heat transport) as discussed in Petty et al. (2012).

In Fig. 11e we see that the mean Weddell Sea surface power input is roughly symmetric (centred around July/August), with no clear winter peak. The Ross Sea mean surface power input has a more pronounced peak in August. The interannual monthly variability is similar. In contrast, the Amundsen Sea mean surface power input tends to peak in April, when the mixed layer is shallow, thereby reducing any dissipative effects, while the Bellingshausen Sea shows a roughly symmetric surface power input centred around June. The mean Ross surface power input is almost double the Weddell throughout autumn/winter, however there is large inter-annual variability across both regions. The Amundsen and Bellingshausen experience a similar surface power input in July, with a lower surface power input in the Bellingshausen across all other months. The Amundsen and Bellingshausen seas both experience a greater surface power output (removal of power from the mixed layer to the atmosphere) in summer, causing a stronger stratification and further reducing the potential mixed-layer deepening in the following winter. This effect is strongest in the Bellingshausen Sea, which has both the lowest power input and largest power output of the four regions.
Figure 12 shows the mean annual energy balance of the mixed layer, calculated through a time integral of the mean power input contributions for each region, with the colours corresponding to the same terms as in Fig. 11a-d. A positive value denotes a net yearly input of energy to the mixed layer, with the deep ocean relaxation removing the excess energy (mainly during spring/summer, representing the advection of more saline waters off the shelf). There is a large input of energy to the WR shelf seas, driven mainly by the salt flux from sea ice growth. The Amundsen shelf sea surface energy input is well balanced, whereas the Bellingshausen shelf sea experiences a net loss of energy due to the large summer freshwater flux from ice melt and also from the freshwater flux due to precipitation. In this case, the loss of energy from the mixed layer must be balanced by diapycnal mixing, represented simply in this model by the relaxation of the mixed layer towards higher salinities.

Figures 11e and 12 show that the greatest input of energy occurs in the Ross Sea, predominantly through the salt flux from ice formation, which in turn depends on the particular atmospheric conditions of the region. This may appear to contradict the observation that the Weddell Sea generates the coldest and most voluminous bottom waters (Gordon et al., 2010). This observation could be explained by either a difference in the waters advecting into the shelf seas that mix with the shelf waters, such as the large flux of freshwater from the Amundsen to the Ross Sea (Assmann and Timmermann, 2005; Jacobs and Giulivi, 2010), or the deeper bathymetry in the Ross Sea along the ice front (Fig. 1), limiting the duration of complete wintertime destratification and thus the rate of salination. The increase in the flux of fresh glacial melt water from the Amundsen to the Ross Sea has been implicated in the recent Ross Sea freshening (Jacobs et al., 2002; Assmann and Timmermann, 2005; Jacobs and Giulivi, 2010), highlighting the additional contribution of this process, which is not included in this study.

\subsection{Regional sea ice mass balance}

As we have confirmed sea ice to be the dominant driver of mixed-layer evolution over the Antarctic shelf seas, we now analyse the sea ice mass balance for the four separate regions, to highlight the differences in the growth, melt and export of ice from each region. The difference in ice growth and melt should equal the ice exported out of the region if we assume the ice to be in a regional steady state. The relative contributions to this balance, however, are important as they will influence the mixed-layer deepening in winter and freshening in summer. If a large fraction of the ice produced in winter is exported away before it can melt in summer, we would expect deeper mixed layers than in a stable case of ice growth equalling ice melt. Alternatively, a net import of ice could provide more ice to melt in summer than was produced the previous winter, providing a fresher summer mixed layer that could inhibit wintertime mixed-layer deepening. 


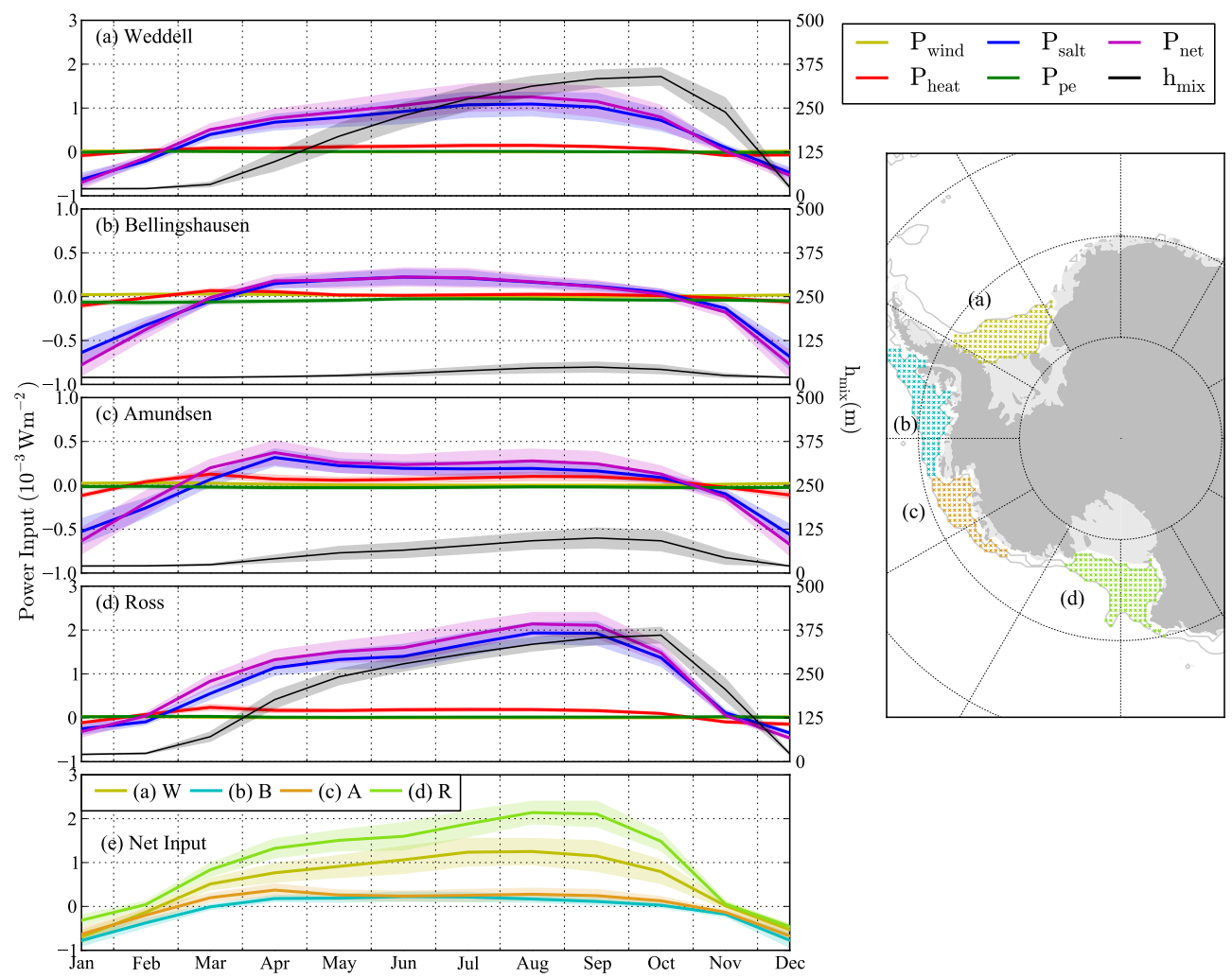

Fig. 11. Mean (1985-2011) surface/mixed-layer (mechanical) power input annual cycle. (a-d) power input from wind mixing (yellow), the ocean/surface-layer heat flux (red), the salt flux from sea ice growth/melt (blue), net precipitation minus evaporation (green), net power input from the addition of all these four terms (magenta) and the mixed-layer depth (black) averaged spatially over each of the four study regions highlighted in the map shown, (e) mean 1985-2011 regional net power input annual cycle. The shading around the lines in (a-e) represents the interannual variability and is equal to one standard deviation from the mean.

Table 2. Regional sea ice mass balance contributions, taken from Fig. 13. The errors shown correspond to one standard deviation in the interannual variability.

\begin{tabular}{lrrrr}
\hline & Weddell & Bellingshausen & Amundsen & Ross \\
\hline Shelf sea area $\left(10^{3} \mathrm{~km}^{2}\right)$ & 450 & 400 & 270 & 460 \\
Ice growth $(\mathrm{m})$ & $2.2 \pm 0.3$ & $1.2 \pm 0.1$ & $1.4 \pm 0.1$ & $2.8 \pm 0.2$ \\
Ice melt $(\mathrm{m})$ & $0.7 \pm 0.1$ & $1.0 \pm 0.2$ & $0.80 \pm 0.1$ & $0.4 \pm 0.1$ \\
Ice export $(\mathrm{m})$ & $1.6 \pm 0.5$ & $0.3 \pm 0.4$ & $0.60 \pm 0.4$ & $2.3 \pm 0.3$ \\
Ice growth $\left(\mathrm{km}^{3}\right)$ & $1020 \pm 110$ & $480 \pm 40$ & $380 \pm 20$ & $1280 \pm 90$ \\
Ice melt $\left(\mathrm{km}^{3}\right)$ & $330 \pm 60$ & $390 \pm 70$ & $210 \pm 30$ & $200 \pm 50$ \\
Ice export $\left(\mathrm{km}^{3}\right)$ & $690 \pm 240$ & $100 \pm 150$ & $160 \pm 120$ & $1100 \pm 150$ \\
Polynya area $\left(10^{3} \mathrm{~km}^{2}\right)$ & 52 & - & - & 97 \\
Polynya growth $(\mathrm{m})$ & $5.0 \pm 0.7$ & - & - & $6.0 \pm 0.4$ \\
Polynya growth $\left(\mathrm{km}^{3}\right)$ & $260 \pm 30$ & - & - & $580 \pm 40$ \\
\hline
\end{tabular}

The annual ice growth and melt in a specific region (in $\mathrm{m}^{3} \mathrm{yr}^{-1}$ ) is calculated as

$$
\begin{aligned}
& G_{\mathrm{i}}(R, \text { year })=\iint_{R} \int_{\text {year }} \frac{\partial V_{\mathrm{i}}^{\mathrm{T}}}{\partial t} \mathrm{~d} T \mathrm{~d} x \mathrm{~d} y \text { where } \frac{\partial V_{\mathrm{i}}^{\mathrm{T}}}{\partial t}>0 \\
& M_{\mathrm{i}}(R, \text { year })=\iint_{R} \int_{\text {year }} \frac{\partial V_{\mathrm{i}}^{\mathrm{T}}}{\partial t} \mathrm{~d} T \mathrm{~d} x \mathrm{~d} y \text { where } \frac{\partial V_{\mathrm{i}}^{\mathrm{T}}}{\partial t}<0
\end{aligned}
$$

where $R$ is the regional shelf sea spatial domain and

$$
\frac{\partial V_{\mathrm{i}}^{\mathrm{T}}}{\partial t}=A \frac{\partial h_{\mathrm{i}}^{\mathrm{T}}}{\partial t}+h_{\mathrm{i}} \frac{\partial A^{\mathrm{T}}}{\partial t},
$$

where $V_{\mathrm{i}}$ is the volume of ice per unit area (in $\mathrm{m}$ ) and the superscript $T$ denotes that the change in ice state is due to thermodynamic processes only. 


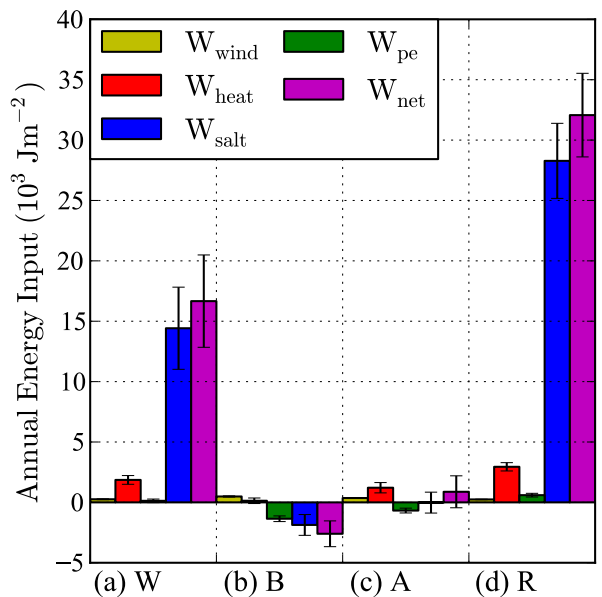

Fig. 12. Mean (1985-2011) annual (mechanical) energy input to the mixed layer from the time integral of each power input term as discussed in Sect. 2.1.2. The error bars shown correspond to one standard deviation from the mean. W: Weddell, B: Bellingshausen, A: Amundsen, R: Ross, which correspond to the shelf sea regions shown in Fig. 11.

The annual ice export out of a specific region (also in $\mathrm{m}^{3} \mathrm{yr}^{-1}$ ) is calculated in a similar fashion as

$E_{\mathrm{i}}(R$, year $)=\iint_{\mathrm{R}} \int_{\text {year }}\left(\nabla \cdot\left(\boldsymbol{u} V_{\mathrm{i}}\right)\right) \mathrm{d} T \mathrm{~d} x \mathrm{~d} y$.

\subsubsection{Results from the regional sea ice mass balance}

Figure 13 shows the sea ice mass balance of the four study regions (see map on right in Fig. 13), with the results summarised in Table 2. The annual regional ice growth in Fig. 13a shows that the Weddell $\left(1020 \pm 110 \mathrm{~km}^{3}\right)$ and Ross $\left(1280 \pm 90 \mathrm{~km}^{3}\right)$ shelf seas grow 2-3 times as much ice each year compared to the Amundsen $\left(380 \pm 20 \mathrm{~km}^{3}\right)$ and Bellingshausen $\left(480 \pm 40 \mathrm{~km}^{3}\right)$ shelf seas. Considering the difference in the size of each shelf sea region, it is also useful to compare this in terms of the mean thickness of ice grown, which normalises the results by the area of each region. The factor of three difference in ice volume growth between the Ross and the Amundsen seas changes to a factor of two when the mean ice thickness growth is considered ( $2.8 \pm 0.2 \mathrm{~m}$ and $1.4 \pm 0.1 \mathrm{~m}$ respectively), due to the relatively small Amundsen shelf sea region. Switching between volume and thickness also changes the region of lowest ice growth, with the lowest mean ice volume growth in the Amundsen, but the lowest mean thickness growth in the Bellingshausen (1.2 $\pm 0.1 \mathrm{~m})$.

Observational estimates of sea ice growth within the shelf seas focus almost solely on polynya ice growth, so we also attempt to estimate the ice growth from coastal polynyas within this model. However, Markus et al. (1998) show that the width of the coastal polynyas in the Weddell Sea can be as low as $5 \mathrm{~km}$ in winter, considerably less than our grid cell width of $\sim 55 \mathrm{~km}$. It is therefore very unlikely that the model will simulate either thin ice (note that Martin et al. (2004) extended the definition of a polynya to include regions where the ice cover is less than $10-20 \mathrm{~cm}$ thick) or a near-zero ice concentration, meaning that we do not expect the model to resolve polynyas. Instead we choose to highlight grid cells with a "high" mean annual ice growth rate, which we take to be $4 \mathrm{~m} \mathrm{yr}^{-1}$. This value corresponds to the lower end of the Tamura et al. (2008) and Drucker et al. (2011) scales and detects strong ice producing ("polynya") grid cells in reasonable locations along the Ross and Ronne ice fronts (highlighted by the black crosses in Fig. 14). This is a useful way of estimating the fractional contribution to shelf sea ice growth from either the rapid ice growth within the small coastal "polynya" regions or the more gradual pack ice growth.

This approach gives a mean Weddell "polynya" growth of $260 \pm 30 \mathrm{~km}^{3}$ and a mean Ross mean growth of $580 \pm 40 \mathrm{~km}^{3}$. To examine how sea ice growth is distributed within the shelf seas, Fig. 14 shows the mean (1985-2011) annual ice growth. Within the Weddell and Ross shelf seas, the ice growth increases towards the southern coastal ice fronts. The cause of this spatial distribution is investigated in more detail in Sect. 3.5. It is expected that latent heat polynyas form in these coastal regions through the strong northward advection of ice away from the coast. Despite the thin ice in the Ross Sea, it is too thick to be classified as a polynya according to the definition of Martin et al. (2004) mentioned earlier. Figure 14 shows the maximum modelled mean annual ice growth at around $8 \mathrm{~m}$ per year, less than the maximum values found in the observational study of Drucker et al. (2011), which calculates a maximum growth of $\sim 15 \mathrm{~m} \mathrm{yr}^{-1}$ in the Weddell and $\sim 28 \mathrm{~m} \mathrm{yr}^{-1}$ in the Ross; however, the larger area the modelled ice growth is calculated over balances (to some degree) the lower area-averaged growth rate.

A number of recent observational studies have attempted to quantify the ice growth from coastal polynyas around Antarctica. Renfrew et al. (2002), Markus et al. (1998), Tamura et al. (2008) and Drucker et al. (2011) all calculate a mean growth in the Ronne Polynya (adjacent to the Ronne Ice Shelf) of $\sim 100 \mathrm{~km}^{3}$. Drucker et al. (2011) also calculate the ice grown in the Eastern Weddell Polynya (EWP) adjacent to the Brunt Ice Shelf, along with a small contribution from a stationary iceberg A23, finding a mean total Weddell polynya ice growth of $240 \pm 30 \mathrm{~km}^{3}$. This compares well to our simulated Weddell polynya growth of $260 \pm 34 \mathrm{~km}^{3}$.

Comparing the estimated Weddell polynya ice growth from both observations and this study to our modelled Weddell shelf sea ice growth of $1020 \pm 110 \mathrm{~km}^{3}$ shows that Weddell polynyas contribute around $20 \%$ to the total Weddell shelf sea ice growth. This matches well the salt/heat budget calculation made by Nicholls et al. (2009), who showed that the heat loss from the Ronne Polynya (which makes up around half the total polynya growth according to 


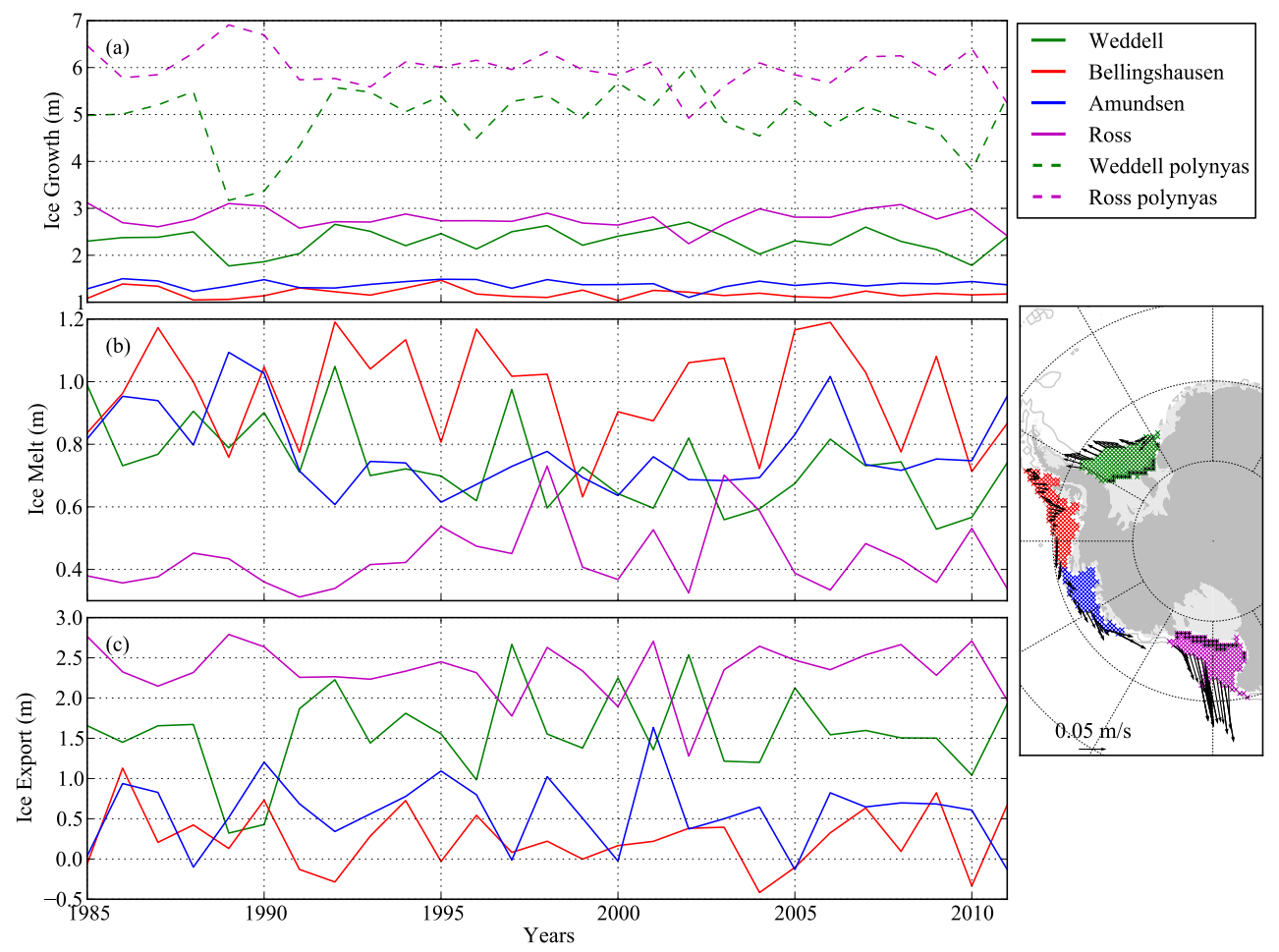

Fig. 13. Annual (1985-2011) regional sea ice mass balance (same regions as Fig. 11). (a) Annual regional ice production, including the contribution from rapid sea ice growth "polynya" grid cells (marked by the black crosses), (b) annual regional ice melt, (c) annual regional net ice export. Mean ice motion vectors for the outer grid cells of each region are shown in the map.

observations) of around $3.5 \times 10^{19} \mathrm{~J}$ from the Renfrew et al. (2002) study accounts for only $10 \%$ of the $3 \times 10^{20} \mathrm{~J}$ heat loss needed to convert MWDW to HSSW. Including the additional $10 \%$ of the total heat loss from the EWP, the remaining $80 \%$ of ice growth required is therefore thought to occur more gradually over the broader shelf sea and is a process lacking in observational analyses. The close fit to this theoretical ratio is an encouraging validation of the model and further highlights the importance of sea ice growth outside of the coastal polynyas.

In the Ross Sea, Martin et al. (2007) and Tamura et al. (2008) calculate a mean ice growth in the coastal polynyas (Ross, McMurdo Sound and Terra Nova Bay polynyas) of $\sim 500 \mathrm{~km}^{3}$, while Drucker et al. (2011) calculate, more recently, a higher mean growth of $740 \pm 90 \mathrm{~km}^{3}$. In all cases the Ross Sea Polynya (RSP) dominates, providing $\sim 80-90 \%$ of the total polynya ice growth. The earlier polynya studies are within error of our polynya estimate of $580 \pm 40 \mathrm{~km}^{3}$.

Comparing the estimated Ross polynya ice growth from both observations and this study to our modelled total Ross shelf sea ice growth of $1300 \pm 90 \mathrm{~km}^{3}$ shows the Ross polynyas contributing around $50 \%$ to the total Ross shelf sea ice growth. Similar to the Weddell Sea, the remaining sea ice growth over the broader continental shelf is a process lacking in observational analyses.
Using this same ice growth calculation procedure, we can estimate the total ice growth of the Weddell $\left(0-60^{\circ} \mathrm{W}\right)$ and Ross $\left(135-195^{\circ} \mathrm{W}\right)$ seas (regions are bounded to the south by the Antarctic coastline and extend northwards wherever sea ice is grown), giving a mean (1985-2011) annual ice growth of $4600 \pm 300 \mathrm{~km}^{3}$ in both the Weddell and the Ross seas. This is considerably higher than the $1800 \mathrm{~km}^{3}$ Weddell ice volume estimate of Renfrew et al. (2002). In our study, the Weddell shelf sea contributes around $20 \%$ to the total Weddell Sea ice growth and the Ross shelf sea contributes around $30 \%$ to the total Ross Sea ice growth.

Comparing the mean annual ice growth map in Fig. 14 with the bottom shelf water formation in Figs. 9 and 10, it is clear that high rates of ice growth are not strictly necessary to cause a complete destratification of the water column. In both regions (Weddell and Ross), destratification extends further north by several grid points from the coast, with an even larger destratification region over the relatively shallow Berkner Bank in the Weddell, which sees only 1-2 $\mathrm{m}$ of ice grown each year. We note, however, that despite the destratification, this does not lead directly to the formation of HSSW but is indirectly important through the cooling of MWDW which intrudes onto the shelf. The consistent ice growth rate along the Ronne Ice Front provides a useful analysis of the impact of bathymetry on shelf water formation, as briefly discussed in the previous section. This shows HSSW formation 


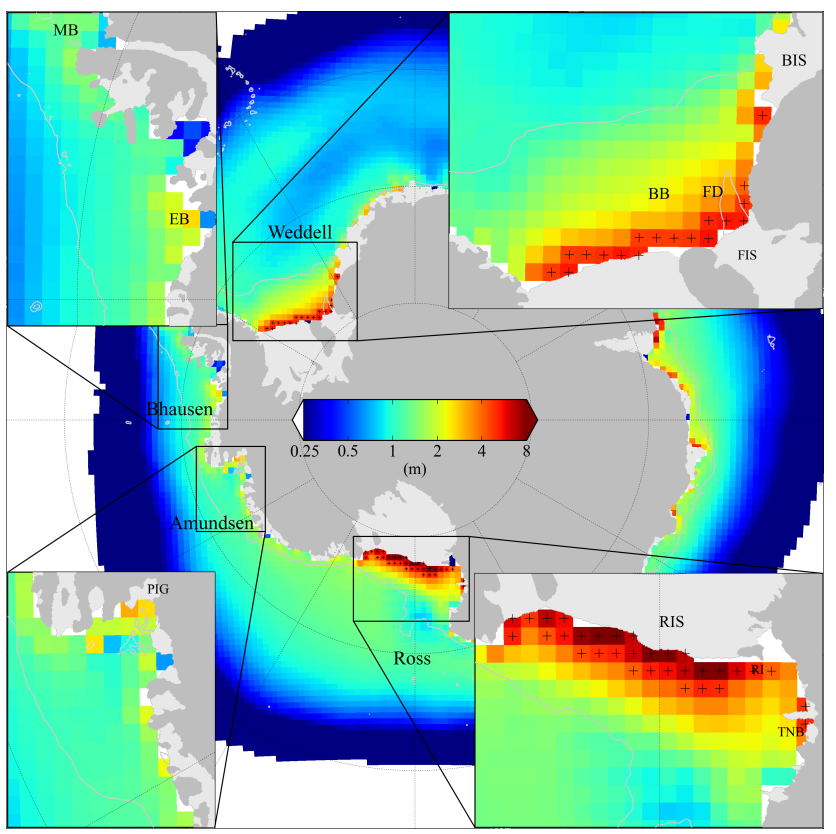

Fig. 14. Mean (1985-2011) annual ice growth. Crosses mark the grid cells where the mean annual ice growth is greater than $4 \mathrm{~m}$. Note that a logarithmic (base 2) colour bar/scale is used. The white line is the $1000 \mathrm{~m}$ isobath contour taken from the RTOPO data set (Timmermann et al., 2010). BB: Berkner Bank, FD: Filchner Depression, FIS: Filchner Ice Shelf, BIS: Brunt Ice Shelf, MB: Marguerite Bay, EB: Eltanin Bay, PIG: Pine Island Glacier, RIS: Ross Ice Shelf, RI: Ross Island, MS: McMurdo Sound, TNB: Terra Nova Bay.

occurring where the water column is at its shallowest (at the southern Berkner Bank), highlighting the potential impact of bathymetry on HSSW formation. This provides further evidence to our earlier hypothesis (Sect. 3.3), that the deeper water column along the Ross Ice Front prevents the Ross Sea from producing more HSSW than the Weddell Sea.

Figure 13b shows the annual regional ice melt. The Bellingshausen shelf sea has the highest mean annual melt $(1.0 \pm 0.2 \mathrm{~m})$ despite having the lowest mean annual ice growth, compared to the Amundsen $(0.8 \pm 0.1 \mathrm{~m})$, Weddell $(0.7 \pm 0.1 \mathrm{~m})$ and Ross $(0.4 \pm 0.1 \mathrm{~m})$ seas. The high Bellingshausen ice melt is due to the strong import of ice (discussed in more detail in the next paragraph) combined with a warm summertime atmosphere. The Amundsen shelf sea also experiences a relatively warm summer and there is a ready supply of ice to melt through the continuous advection of ice from the Bellingshausen Sea. The Ross Sea rapidly advects ice away from the shelf, reducing the amount of ice available to melt in summer. The Weddell Sea also advects ice northwards but at a slower rate than the Ross, increasing the amount of ice available to melt. Both the Ross and the Weddell shelf seas are forced by a colder atmosphere in summer than the Amundsen and Bellingshausen.
The annual regional ice export is shown in Fig. 13c. Note the high inter-annual variability in ice export compared to the other two terms in the sea ice mass balance. There is a large export of ice from the Weddell $(1.6 \pm 0.5 \mathrm{~m})$ and Ross $(2.3 \pm 0.3 \mathrm{~m})$ shelf seas and a low export from the Amundsen $(0.6 \pm 0.4 \mathrm{~m})$ and Bellingshausen $(0.3 \pm 0.4 \mathrm{~m})$ shelf seas. The ice is advected to the north of the Weddell and Ross shelf seas (shown by the ice motion vectors at the shelf edge in Fig. 13c), driven by strong meridional winds, especially in the Ross, as shown in Fig. 2a, removing much of the ice that is grown in winter before it is able to melt in summer (except for a period in the late 1980s where the Weddell export reduces dramatically to near the $\mathrm{AB}$ export). Considering the significantly higher meridional wind speed in the Ross, it is perhaps surprising that the difference between the Weddell and Ross export is not greater. An important factor here is the thickness of the ice that is being exported (shown in Fig. 7) with the thicker ice in the Weddell compensating to some degree the reduced meridional ice speed. In contrast, the eastern $\mathrm{AB}$ shelf seas show a net import of ice, which is strongest in the eastern Bellingshausen sea, although this is exceeded by a net export of ice to the west of each region. Despite a mean net export of ice out of the Bellingshausen shelf sea, a net import (negative export) is within one standard deviation of the mean. Ice advection between the Bellingshausen and Amundsen seas likely plays an important role in each regional mass balance. However, due to the thin width of the connecting shelf sea and the complex coastal geometry of the Amundsen Sea embayment, it is unlikely that our model will capture this process accurately, as discussed earlier in Sect. 3.1.

Comparing the modelled ice export with observations in the Weddell, Drucker et al. (2011) calculate a mean (1992-2008) export of $390 \pm 130 \mathrm{~km}^{3}$ (through a straightline flux gate centred over the $1000 \mathrm{~m}$ deep shelf break) using the motion-tracking area flux estimation of Kwok (2005) combined with an ICESat estimate of Weddell shelf sea ice thickness $(0.75 \pm 0.25 \mathrm{~m})$ of Yi et al. (2011). This is the only known estimate of Weddell shelf ice export and is lower than, but just within, the $690 \pm 240 \mathrm{~km}^{3}$ range (plus or minus one standard deviation of the modelled interannual variability) found in this study.

Drucker et al. (2011) calculate a mean (1992-2008) Ross ice export of $700 \pm 350 \mathrm{~km}^{3}$ using the motion tracking area flux estimation of Kwok (2005) and in situ Ross shelf sea ice thickness $(0.6 \pm 0.3 \mathrm{~m})$ of Jeffries and Adolphs (1997). This is similar to the Comiso et al. (2011) value of $600 \pm 470 \mathrm{~km}^{3}$ which used a similar method and data set. These values are lower than, but within range of, the $1100 \pm 150 \mathrm{~km}^{3}$ value found in this study. In both cases, the Kwok (2005) flux gate used lies to the north of the shelf break in the east, where there is a tendency for ice import, and to the south of the shelf break in the west, where there is a tendency for export. It is therefore expected that the Comiso et al. (2011) and Drucker et al. (2011) estimates are a lower bound of the 
expected export past the $1000 \mathrm{~m}$ isobath contour. The only other known estimate of Ross export is that of Jacobs et al. (2002), which used a simple calculation involving NCEP surface winds and the Jeffries and Adolphs (1997) ice thickness to obtain an estimated export of $1000 \pm 300 \mathrm{~km}^{3}$, closer to the value found in this study.

There has been little observational analysis of the Amundsen and Bellingshausen shelf sea ice growth and export. Tamura et al. (2008) show small coastal polynyas in the Eltanin Bay in the Bellingshausen Sea, corresponding to our peak region of ice growth in the Bellingshausen shelf sea shown in Fig. 14, and in the Amundsen Sea embayment, which is not apparent in our study. Assmann and Timmermann (2005) is the only study known to us that has attempted to quantify the ice transport through the Amundsen Sea, using the Bremerhaven Regional Ice Ocean Simulations (BRIOS) model, calculating a mean (1978-2001) annual ice export of $536 \pm 347 \mathrm{~km}^{3}$. This value is higher than, but within range of the $160 \pm 120 \mathrm{~km}^{3}$ found in this study. The region in Assmann and Timmermann (2005) for which ice export is calculated extends further north of the shelf break, increasing the potential advection of ice to the north.

\subsection{Linear correlation analysis}

To understand the link between spatial (temporal mean intra-regional variability) and temporal (shelf sea mean - interannual variability) atmospheric variability on the surfacedriven deepening of the mixed layer, this section investigates the linear correlation between various atmospheric variables and the net surface power input to the mixed layer in autumn/winter (April-September). Specifically, Table 3 demonstrates the spatial correlation between the temporal mean (1985-2011) autumn/winter atmospheric forcing and the temporal mean (1985-2011) autumn/winter surface power input, with one point used for each grid cell within the regions shown in Fig. 11. Figure 15 demonstrates the temporal correlation between the shelf-sea spatial mean autumn/winter atmospheric forcing to the shelf-sea spatial mean autumn/winter net surface power input, with one point used for each year for each region. This regression is shown graphically to demonstrate the variability in the mean atmospheric forcing over each of the shelf seas. The potential for summer stratification preconditioning the following winter mixed-layer deepening has been discussed previously (e.g. by Meredith et al., 2004, for the Bellingshausen Sea) and so it is included as a further variable in both studies. All variables are regressed against the mean net surface power input in autumn/winter (April-September) as this represents both the mixed-layer deepening and potential salinification of the mixed layer. Note that in the following discussion, we take $r^{2}<0.2$ to imply weak correlation, an $r^{2}$ of $0.2-0.5$ to imply moderate correlation, and an $r^{2}>0.5$ to imply strong correlation. Correlations discussed are significant at $99 \%$ un-
Table 3. Spatial linear regression of the temporal mean (1985-2011) autumn/winter (April-September) net surface power input to the mixed layer against the temporal mean (1985-2011) autumn/winter: $2 \mathrm{~m}$ air temperature, $2 \mathrm{~m}$ specific humidity, incoming long-wave radiation, incoming short-wave radiation, total precipitation (rain and snow), $10 \mathrm{~m}$ zonal (positive eastwards) wind speed, $10 \mathrm{~m}$ meridional (positive northwards) wind speed, and summer (January-March) net surface power input, for each of the regions shown in Fig. 11. Each regressed data point corresponds to a specific grid cell and represents the grid point temporal mean value. The coefficient of determination $\left(r^{2}\right)$ is shown in the table, where significant $(>99 \%$ ) correlations are highlighted in bold. The sign in parentheses indicates the sign of the respective $r$ value. Note that $F_{\text {rain }}+F_{\text {snow }}=P$ as in Fig. $2 \mathrm{f}$.

\begin{tabular}{llrrr}
\hline$P_{\text {net }}^{A-S}$ & Weddell & Bellingshausen & Amundsen & Ross \\
\hline$T_{\mathrm{a}}$ & $\mathbf{0 . 2 4}(-)$ & $\mathbf{0 . 2 7}(-)$ & $\mathbf{0 . 1 4}(-)$ & $\mathbf{0 . 5 4}(-)$ \\
$Q_{a}$ & $\mathbf{0 . 3 0}(-)$ & $\mathbf{0 . 2 3}(-)$ & $\mathbf{0 . 1 4}(-)$ & $\mathbf{0 . 4 4}(-)$ \\
$F_{\text {lwin }}$ & $0.04(-)$ & $\mathbf{0 . 2 5}(-)$ & $\mathbf{0 . 1 4}(-)$ & $0.02(-)$ \\
$F_{\text {sw }}$ & $\mathbf{0 . 4 3}(-)$ & $\mathbf{0 . 1 8}(-)$ & $\mathbf{0 . 1 3}(-)$ & $\mathbf{0 . 3 6}(-)$ \\
$F_{\text {rain }}+F_{\text {snow }}$ & $0.00(+)$ & $0.01(-)$ & $0.01(+)$ & $\mathbf{0 . 0 9}(-)$ \\
$U$ & $\mathbf{0 . 1 8}(-)$ & $\mathbf{0 . 2 1}(-)$ & $\mathbf{0 . 0 9}(-)$ & $\mathbf{0 . 0 8}(-)$ \\
$V$ & $\mathbf{0 . 0 7}(-)$ & $\mathbf{0 . 3 3}(+)$ & $0.05(+)$ & $0.00(-)$ \\
$P_{\text {net }}^{J-M}$ & $\mathbf{0 . 5 5}(+)$ & $0.00(+)$ & $\mathbf{0 . 2 6}(+)$ & $\mathbf{0 . 8 1}(+)$ \\
\hline
\end{tabular}

less otherwise stated (non-significant $(<99 \%)$ correlations are also listed in the table/figure).

Considering the moderate/strong significant autumn/winter net surface power input spatial (temporal mean - intra-regional variability) correlations ( $r^{2}$ values $)$ listed in Table 3, the Weddell and Ross both show strong spatial correlation to the summer (January-March) net surface power input, and moderate/strong correlation to incoming short-wave radiation, specific humidity and air temperature. The Bellingshausen shows moderate spatial correlation to several forcing variables, while the Amundsen shows only moderate spatial correlation to the summer net surface power input.

We expected that the autumn/winter net surface power input would show a consistently strong spatial correlation to air temperature, based on the study of Petty et al. (2012) which demonstrated the large impact of air temperature on mixedlayer depth variability. However, the more sophisticated 2-D ice dynamics of CICE complicates the results of the simple sea ice model by advecting ice into neighbouring grid cells, affecting their resultant thermodynamic behaviour. A combination of low air temperatures, high ice growth and strong net export of ice out of a grid cell should lead to a consistently greater winter destratification, i.e. the process taking place along the coastal ice fronts, where ice is only advected northwards without any import of ice from the south. The perennially thin ice cover in the Ross Sea probably explains the greater correlation between intra-regional atmospheric variability and the net surface power input, with the thicker ice present in the other shelf seas insulating them 

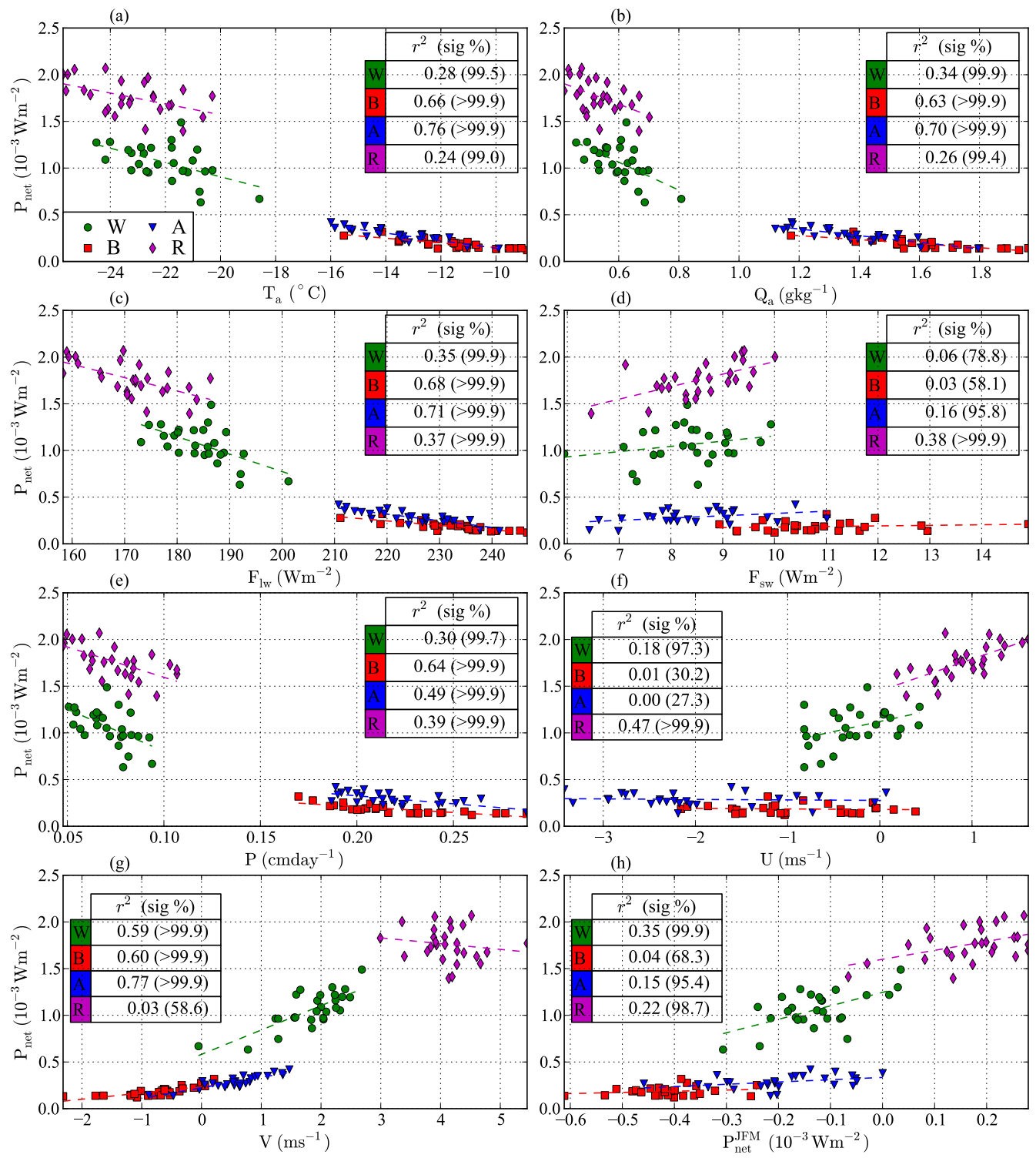

Fig. 15. Linear temporal correlation of the spatial (shelf sea) mean autumn/winter (April-September) net surface power input to the mixed layer against the spatial mean autumn/winter: (a) $2 \mathrm{~m}$ air temperature, (b) $2 \mathrm{~m}$ specific humidity, (c) incoming long-wave radiation, (d) incoming short-wave radiation, (e) total precipitation (rain and snow), (f) $10 \mathrm{~m}$ zonal wind speed, (g) $10 \mathrm{~m}$ meridional wind speed and (h) summer net surface power input, for the grid points representing each region shown in Fig. 11. Each coloured data point represents a shelf sea and corresponds to the shelf sea annual value. The linear regression lines of each shelf sea data set are shown by the dashed lines, with the coefficient of determination $\left(r^{2}\right)$ and significance of the correlation shown in the tables within each panel.

against any intra-regional atmospheric variability. The lack of strong spatial correlation with the winds is unsurprising, as it is the ice divergence that plays the crucial role locally, where we expect the divergence to be at a maximum near the coast, which might not necessarily correspond to regions of stronger winds. The high ice growth rates near to the coast and the continuous export of ice to the north in the Weddell and Ross Seas (as described earlier in Sect. 3.4.1) will lead to a greater autumn/winter net surface power input and will reduce the availability of ice to melt in summer. This could also explain the strong correlation between the summer net surface power input and autumn/winter surface power input as opposed to the causative impact of less summer melt and therefore a less stratified summer water column on the subsequent mixed-layer deepening. However, this could also be an additional positive feedback.

Considering the moderate/strong significant autumn/winter net surface power input temporal (shelf sea mean - interannual variability) correlations ( $r^{2}$ values) shown in Fig. 15, the Amundsen and Bellingshausen both 
show strong temporal correlation to incoming long-wave radiation, air temperature, specific humidity and meridional wind speed. The Weddell shows strong temporal correlation to the meridional wind speed, and moderate correlation to several thermodynamic forcings. The Ross shows only moderate temporal correlation to the zonal wind speed, and several thermodynamic forcings. Note that all variables in this temporal correlation show less variance than in the spatial correlations described above (i.e. atmospheric and summer power input show greater spatial variance within each shelf sea compared to the mean shelf sea temporal variability).

The weaker correlations in the Weddell and Ross may be due to ocean feedbacks as a result of deeper mixed layers such as an enhanced ocean heat flux, or the weaker correlation between the atmospheric variables due to stronger winds. The strong correlation to meridional winds compared to zonal winds in the Amundsen and Bellingshausen can be explained by the mean ice motion and geometry of the regions (Fig. 6). Only a more northward (positive) meridional wind anomaly could increase divergence, as a more westward (negative) zonal flow would simply increase both the import of ice from the east and export to the west of each region.

An interesting result is the lack of correlation between the net surface power input and the meridional wind speed in the Ross. Intuitively we might expect that stronger meridional winds would lead to greater net ice divergence and thus increased ice production, as we see in the Weddell. Further correlations (not shown) were carried out to investigate this in more detail. The annual Ross ice export $\left(E_{\mathrm{i}}\right)$ shows a moderate correlation to the zonal wind speed $(0.28)$, but no correlation to the meridional wind speed. A moderate anticorrelation (0.27) was calculated between the autumn/winter meridional and zonal wind speeds. These results are thought to be due to the location of the Ross Sea pressure low (as discussed in more detail by Comiso et al., 2011), where specific locations of the low change the orientation of the isobars across the shelf, meaning that greater meridional winds reduce the zonal component of the wind (less eastward) and vice versa. A more eastward wind direction will result in ice being advected more perpendicular to both the ice front and shelf break, away from the Cape Adare coast, increasing the total shelf sea ice divergence. A complicating factor in this discussion is the impact of ice thickness on the resultant link between winds and export, which was highlighted by Comiso et al. (2011) as a key area of uncertainty in such discussions.

\section{Conclusions}

A prognostic mixed-layer model has been incorporated into the Los Alamos sea ice model CICE, to investigate the cause of regional variations in the formation of Antarctic shelf sea waters. This model captures reasonably well the expected ice concentration and sea ice thickness distribution through comparison to observations and produces deep $(>500 \mathrm{~m})$ mixed layers in the Weddell and Ross shelf seas each winter as expected. This results in the complete destratification of the water column along the southern coastal ice fronts in both seas, leading to high-salinity shelf water (HSSW) formation. The water column is also destratified in shallow regions further north (e.g. the Berkner Bank in the central Weddell shelf) which do not lead to HSSW formation but do provide an important mechanism through which Modified Warm Deep Water (MWDW) is converted to near HSSW. Shallow mixed layers form in the Amundsen $(\sim 200 \mathrm{~m})$ and Bellingshausen $(<100 \mathrm{~m})$ shelf seas.

By deconstructing the surface processes driving the mixed-layer depth evolution (surface/mixed-layer mechanical power input), we find that the net salt flux from sea ice growth/melt dominates the evolution of the mixed layer in all regions, with a smaller contribution from the surface heat flux. Wind mixing provides a negligible direct input of power to the mixed layer, however it is likely an important factor in controlling the regional ice distribution.

The Weddell and Ross shelf seas receive a net input of energy at the surface (mainly through the autumn/winter salt flux), which is used to convert MWDW to HSSW, with the excess energy removed each year through deep-ocean restoring, which represents ocean dynamics neglected by this model. The Amundsen shelf sea is well balanced, with the surface input of energy in autumn/winter balanced by the loss of energy from surface forcing in spring/summer. The Bellingshausen shelf sea experiences an annual surface energy deficit, due primarily to a strong freshwater flux in spring/summer.

An analysis of the sea ice mass balance demonstrates the contrasting growth, melt and export of ice in each region. The Ross shelf sea has the highest mean annual ice growth, followed by the Weddell shelf sea, with the two regions growing two/three times as much ice as the Amundsen and Bellingshausen shelf seas. The Bellingshausen shelf sea has the highest mean annual ice melt of the shelf seas, driven in large part by the warm summer atmosphere and continuous ice import from the northeast, which explains the strong summer stratification and shallow mixed layers that form here in winter. In contrast, a large fraction of the ice that is grown over the Weddell and Ross shelves is exported to the north each year ( $\gtrsim 40 \%$ and $\gtrsim 70 \%$ respectively). These results compare well with the estimated ice growth needed for MWDWHSSW conversion in the Weddell Sea calculated by Nicholls et al. (2009), and both the Weddell and Ross export estimates lie within the ranges calculated by Drucker et al. (2011). Comparing our modelled ice growth estimates to polynya ice growth observations suggests that the coastal polynyas contribute $\sim 20 \%$ to Weddell shelf sea ice growth and $\sim 50 \%$ to the Ross shelf sea ice growth. Sea ice growth outside the Ross and Weddell coastal polynyas is therefore expected to 
be an important shelf sea process that currently lacks observational analysis.

A linear regression analysis is performed to determine the spatial (temporal mean - intra-regional variability) and temporal (shelf sea mean - interannual variability) correlations between the autumn/winter surface/mixed-layer power input (representing mixed-layer deepening/salination) and several atmospheric variables. The Weddell and Ross show strong spatial (temporal mean - intra-regional variability) correlation to the summer surface power input and moderate correlation to the autumn/winter air temperature, specific humidity and incoming short-wave radiation. The Bellingshausen shows moderate spatial correlation to several atmospheric variables, while the Amundsen shows only a moderate spatial correlation to the summer surface power input.

The Amundsen and Bellingshausen show strong temporal (shelf sea mean - interannual variability) correlation to air temperature, incoming long-wave radiation and specific humidity, while the Weddell and Ross show only a moderate temporal correlation to the same forcings. All regions show strong temporal correlation to the meridional wind speed except the Ross, which instead shows moderate temporal correlation to the zonal wind speed. Further regressions highlight the potential importance of the Ross shelf-sea geometry and impact of the ocean turning angle on ice motion, whereby more zonal winds result in ice being advected more perpendicular to both the ice front and shelf break, and away from the Cape Adare coast.

\section{Supplementary material related to this article is available online at http://www.the-cryosphere.net/8/761/ 2014/tc-8-761-2014-supplement.pdf.}

Acknowledgements. We would like to thank D. Schroeder for assistance in the initial CICE configuration and in acquiring and re-gridding the atmospheric forcing sets used in this study. We would also like to thank Laurie Padman and one anonymous reviewer for their insightful and constructive comments.

Edited by: R. Lindsay

\section{References}

Antonov, J. I., Seidov, D., Boyer, T. P., Locarnini, R. A., Mishonov, A. V., Garcia, H. E., Baranova, O. K., Zweng, M. M., and Johnson, D. R.: World Ocean Atlas 2009, vol. 2: Salinity, edited by: Levitus, S., NOAA Atlas NESDIS, 69, 184 pp., 2010.

Arneborg, L., Wahlin, A. K., Bjork, G., Liljebladh, B., and Orsi, A. H.: Persistent inflow of warm water onto the central Amundsen shelf, Nat. Geosci., 5, 876-880, doi:10.1038/ngeo1644, 2012.
Årthun, M., Nicholls, K. W., and Boehme, L.: Wintertime Water Mass Modification near an Antarctic Ice Front, J. Phys. Oceanogr., 43, 359-365, doi:10.1175/JPO-D-12-0186.1, 2012.

Assmann, K. and Timmermann, R.: Variability of dense water formation in the Ross Sea, Ocean Dynam., 55, 68-87, doi:10.1007/ s10236-004-0106-7, 2005.

Assmann, K. M., Hellmer, H. H., and Jacobs, S. S.: Amundsen Sea ice production and transport, J. Geophys. Res., 110, C12013, doi:10.1029/2004JC002797, 2005.

Assmann, K. M., Jenkins, A., Shoosmith, D. R., Walker, D. P., Jacobs, S. S., and Nicholls, K. W.: Variability of Circumpolar Deep Water transport onto the Amundsen Sea Continental shelf through a shelf break trough, J. Geophys. Res.-Oceans, 118, 118, doi:10.1002/2013JC008871, 2013.

Bitz, C. M. and Lipscomb, W. H.: An energy-conserving thermodynamic model of sea ice, J. Geophys. Res., 104, 15669-15677, doi:10.1029/1999JC900100, 1999.

Comiso, J.: Bootstrap Sea Ice Concentrations from Nimbus-7 SMMR and DMSP SSM/I-SSMIS, Boulder, Colorado USA: National Snow and Ice Data Center, 1999.

Comiso, J. C., Kwok, R., Martin, S., and Gordon, A. L.: Variability and trends in sea ice extent and ice production in the Ross Sea, J. Geophys. Res., 116, C04021, doi:10.1029/2010JC006391, 2011.

de Steur, L., Holland, D., Muench, R., and McPhee, M.: The warm-water Halo around Maud Rise: Properties, dynamics and Impacts, Deep-Sea Res. Pt. I, 54, 871-896, doi:10.1016/j.dsr.2007.03.009, 2007.

Dee, D. P., Uppala, S. M., Simmons, A. J., Berrisford, P., Poli, P., Kobayashi, S., Andrae, U., Balmaseda, M. A., Balsamo, G., Bauer, P., Bechtold, P., Beljaars, A. C. M., van de Berg, L., Bidlot, J., Bormann, N., Delsol, C., Dragani, R., Fuentes, M., Geer, A. J., Haimberger, L., Healy, S. B., Hersbach, H., Hólm, E. V., Isaksen, L., Kôllberg, P., Köhler, M., Matricardi, M., McNally, A. P., Monge-Sanz, B. M., Morcrette, J.-J., Park, B.-K., Peubey, C., de Rosnay, P., Tavolato, C., Thópaut, J.-N., and Vitart, F. The ERA-Interim reanalysis: configuration and performance of the data assimilation system, Q. J. Roy. Meteor. Soc., 137, 553597, doi:10.1002/qj.828, 2011.

Drucker, R., Martin, S., and Kwok, R.: Sea ice production and export from coastal polynyas in the Weddell and Ross Seas, Geophys. Res. Lett., 38, L17502, doi:10.1029/2011GL048668, 2011.

Dutrieux, P., De Rydt, J., Jenkins, A., Holland, P. R., Ha, H. K., Lee, S. H., Steig, E. J., Ding, Q., Abrahamsen, E. P., and Schröder, M.: Strong Sensitivity of Pine Island IceShelf Melting to Climatic Variability, Science, 343, 174-178, doi:10.1126/science.1244341, 2014.

Fahrbach, E., Peterson, R., Rohardt, G., Schlosser, P., and Bayer, R.: Suppression of bottom water formation in the southeastern Weddell sea, Deep Sea Res. Pt. 1, 41, 389-411, 1994.

Foldvik, A., Gammelsrød, T., Østerhus, S., Fahrbach, E., Rohardt, G., Schroder, M., Nicholls, K. W., Padman, L., and Woodgate, R. A.: Ice shelf water overflow and bottom water formation in the southern Weddell Sea, J. Geophys. Res., 109, C02015, doi:10.1029/2003JC002008, 2004.

Foster, T. D. and Carmack, E. C.: Frontal zone mixing and Antarctic Bottom water formation in the southern Weddell Sea, Deep Sea Research and Oceanographic Abstracts, 23, 301-317, 1976.

Fricker, H. A. and Padman, L.: Thirty years of elevation change on Antarctic Peninsula ice shelves from multimission 
satellite radar altimetry, J. Geophys. Res., 117, C02026, doi:10.1029/2011JC007126, 2012.

Gill, A. E.: Circulation and bottom water production in the Weddell Sea, Deep Sea Research and Oceanographic Abstracts, 20, 111140, 1973.

Gordon, A. L., Huber, B. A., Hellmer, H. H., and Ffield, A.: Deep and Bottom Water of the Weddell Sea's Western Rim, Science, 262, 95-97, 1993.

Gordon, A. L., Huber, B., McKee, D., and Visbeck, M.: A seasonal cycle in the export of bottom water from the Weddell Sea, Nat. Geosci., 3, 551-556, 2010.

Hibler, W. D.: A Dynamic Thermodynamic Sea Ice Model, J. Phys. Oceanogr., 9, 815-846, 1979.

Holland, P. R. and Kwok, R.: Wind-driven trends in Antarctic seaice drift, Nat. Geosci., 5, 872-875, doi:10.1038/ngeo1627, 2012.

Holland, P. R., Jenkins, A., and Holland, D. M.: Ice and ocean processes in the Bellingshausen Sea, Antarctica, J. Geophys. Res., 115, C05020, doi:10.1029/2008JC005219, 2010.

Hunke, E. C. and Dukowicz, J. K.: An Elastic Viscous Plastic Model for Sea Ice Dynamics, J. Phys. Oceanogr., 27, 1849-1867, 1997.

Hunke, E. C. and Lipscomb, W. H.: CICE: the Los Alamos Sea Ice Model Documentation and Software User's Manual Version 4.1, LA-CC-06-012, T-3 Fluid Dynamics Group, Los Alamos National Laboratory, Los Alamos, 2010.

Jacobs, S. S.: Bottom water production and its links with the thermohaline circulation, Antarct. Sci., 16, 427-437, doi:10.1017/S095410200400224X, 2004.

Jacobs, S. S. and Giulivi, C. F.: Large Multidecadal Salinity Trends near the Pacific-Antarctic Continental Margin, J. Climate, 23, 4508-4524, doi:10.1175/2010JCLI3284.1, 2010.

Jacobs, S. S., Amos, A. F., and Bruchhausen, P. M.: Ross Sea oceanography and Antarctic Bottom Water formation, Deep Sea Research and Oceanographic Abstracts, 17, 935-962, 1970.

Jacobs, S. S., Fairbanks, R. G., and Horibe, Y. G.: Origin and evolution of water masses near the Antarctic continental margin: Evidence from $\mathrm{H}_{2}^{18} \mathrm{O} / \mathrm{H}_{2}^{16} \mathrm{O}$ ratios in seawater, in: Antarct. Res. Ser., vol. 43, 59-85, AGU, Washington, DC, doi:10.1029/AR043p0059, 1985.

Jacobs, S. S., Hellmer, H. H., and Jenkins, A.: Antarctic Ice Sheet melting in the Southeast Pacific, Geophys. Res. Lett., 23, 957960, doi:10.1029/96GL00723, 1996.

Jacobs, S. S., Giulivi, C. F., and Mele, P. A.: Freshening of the Ross Sea During the Late 20th Century, Science, 297, 386-389, doi:10.1126/science.1069574, 2002.

Jacobs, S. S., Jenkins, A., Giulivi, C. F., and Dutrieux, P.: Stronger ocean circulation and increased melting under Pine Island Glacier ice shelf, Nat. Geosci., 4, 519-523, doi:10.1038/ngeo1188, 2011.

Jacobs, S. S., Jenkins, A., Hellmer, H., Giulivi, C., Nitsche, F., Huber, B., and Guerrero, R.: The Amundsen Sea and the Antarctic Ice Sheet, Oceanography, 25, 154-163, doi:10.5670/oceanog.2012.90, 2012.

Jeffries, M. O. and Adolphs, U.: Early winter ice and snow thickness distribution, ice structure and development of the western Ross Sea pack ice between the ice edge and the Ross Ice Shelf, Antarct. Sci., 9, 188-200, 1997.

Jenkins, A. and Jacobs, S.: Circulation and melting beneath George VI Ice Shelf, Antarctica, J. Geophys. Res., 113, C04013, doi:10.1029/2007JC004449, 2008.
Johnson, G. C.: Quantifying Antarctic Bottom Water and North Atlantic Deep Water volumes, J. Geophys. Res., 113, C05027, doi:10.1029/2007JC004477, 2008.

Kim, J.-W.: A Generalized Bulk Model of the Oceanic Mixed Layer, J. Phys. Oceanogr., 6, 686-695, 1976.

Kimura, N.: Sea Ice Motion in Response to Surface Wind and Ocean Current in the Southern Ocean, J. Meteoro. S. Jpn., 82, 12231231, 2004.

Klinck, J., Hofmann, E., Beardsley, R., Salihoglu, B., and Howard, S.: Water-mass properties and circulation on the west Antarctic Peninsula Continental Shelf in Austral Fall and Winter 2001, Deep Sea Res. Pt. II, 51, 1925-1946, doi:10.1016/j.dsr2.2004.08.001, 2004.

Kraus, E. B. and Turner, J. S.: A one-dimensional model of the seasonal thermocline II. The general theory and its consequences, Tellus, 19, 98-106, doi:10.1111/j.2153-3490.1967.tb01462.x, 1967.

Kurtz, N. T. and Markus, T.: Satellite observations of Antarctic sea ice thickness and volume, J. Geophys. Res., 117, C08025, doi:10.1029/2012JC008141, 2012.

Kwok, R.: Ross Sea Ice Motion, Area Flux, and Deformation, J. Climate, 18, 3759-3776, doi:10.1175/JCLI3507.1, 2005.

Lemke, P. and Manley, T. O.: The Seasonal Variation of the Mixed Layer and the Pycnocline Under Polar Sea Ice, J. Geophys. Res., 89, 6494-6504, doi:10.1029/JC089iC04p06494, 1984.

Lemke, P., Owens, W. B., and Hibler, W. D.: A Coupled Sea IceMixed Layer-Pycnocline Model for the Weddell Sea, J. Geophys. Res., 95, 9513-9525, doi:10.1029/JC095iC06p09513, 1990.

Lindsay, R. W., Holland, D. M., and Woodgate, R. A.: Halo of low ice concentration observed over the Maud Rise seamount, Geophys. Res. Lett., 31, L13302, doi:10.1029/2004GL019831, 2004.

Locarnini, R. A., Mishonov, A. V., Antonov, J. I., Boyer, T. P., Garcia, H. E., Baranova, O. K., Zweng, M. M., and Johnson, D. R.: World Ocean Atlas 2009, Vol. 1: Temperatures, edited by: Levitus, S., NOAA Atlas NESDIS 68, 2010.

Markus, T., Kottmeier, C., and Fahrbach, E.: Ice formation in coastal polynyas In the Weddell Sea and their impact on oceanic salinity, in: Antarctic Sea Ice: Physical Processes, Interactions and Variability, 273-292, American Geophysical Union, doi:10.1029/AR074p0273, 1998.

Martin, S., Drucker, R., Kwok, R., and Holt, B.: Estimation of the thin ice thickness and heat flux for the Chukchi Sea Alaskan coast polynya from Special Sensor Microwave/Imager data, 1990-2001, J. Geophys. Res., 109, C10012, doi:10.1029/2004JC002428, 2004.

Martin, S., Drucker, R. S., and Kwok, R.: The areas and ice production of the western and central Ross Sea polynyas, 1992-2002, and their relation to the B-15 and C-19 iceberg events of 2000 and 2002, J. Marine Syst., 68, 201-214, doi:10.1016/j.jmarsys.2006.11.008, 2007.

Martinson, D. G. and McKee, D. C.: Transport of warm Upper Circumpolar Deep Water onto the western Antarctic Peninsula continental shelf, Ocean Sci., 8, 433-442, doi:10.5194/os-8-4332012, 2012.

Martinson, D. G., Stammerjohn, S. E., Iannuzzi, R. A., Smith, R. C., and Vernet, M.: Western Antarctic Peninsula physical oceanography and spatio-temporal variability, Deep Sea Res. Pt. II,, 55, 1964-1987, doi:10.1016/j.dsr2.2008.04.038, 2008. 
Maykut, G. A. and Untersteiner, N.: Some Results from a TimeDependent Thermodynamic Model of Sea Ice, J. Geophys. Res., 76, 1550-1575, doi:10.1029/JC076i006p01550, 1971.

Meredith, M. P., Renfrew, I. A., Clarke, A., King, J. C., and Brandon, M. A.: Impact of the 1997/98 ENSO on upper ocean characteristics in Marguerite Bay, western Antarctic Peninsula, J. Geophys. Res., 109, C09013, doi:10.1029/2003JC001784, 2004.

Meredith, M. P., Wallace, M. I., Stammerjohn, S. E., Renfrew, I. A., Clarke, A., Venables, H. J., Shoosmith, D. R., Souster, T., and Leng, M. J.: Changes in the freshwater composition of the upper ocean west of the Antarctic Peninsula during the first decade of the 21st century, Prog. Oceanogr., 87, 127-143, doi:10.5194/os8-433-2012, 2010.

Nicholls, K. W., Padman, L., Schröder, M., Woodgate, R. A., Jenkins, A., and Østerhus, S.: Water mass modification over the continental shelf north of Ronne Ice Shelf, Antarctica, J. Geophys. Res., 108, 3260, doi:10.1029/2002JC001713, 2003.

Nicholls, K. W., Boehme, L., Biuw, M., and Fedak, M. A.: Wintertime ocean conditions over the southern Weddell Sea continental shelf, Antarctica, Geophys. Res. Lett., 35, L21605, doi:10.1029/2008GL035742, 2008.

Nicholls, K. W., Østerhus, S., Makinson, K., Gammelsrød, T., and Fahrbach, E.: Ice-ocean processes over the continental shelf of the southern Weddell Sea, Antarctica: A review, Rev. Geophys., 47, RG3003, doi:10.1029/2007RG000250, 2009.

Niiler, P. and Kraus, E. B.: One-dimensional models of the upper ocean, Modeling and prediction of the upper layers of the ocean, Pergamon Press, New York, 143-172, 1977.

Ohshima, K. I., Fukamachi, Y., Williams, G. D., Nihashi, S., Roquet, F., Kitade, Y., Tamura, T., Hirano, D., HerraizBorreguero, L., Field, I., Hindell, M., Aoki, S., and Wakatsuchi, M.: Antarctic Bottom Water production by intense sea-ice formation in the Cape Darnley polynya, Nat. Geosci., advance online publication, doi:10.1038/ngeo1738, 2013.

Orsi, A. H. and Wiederwohl, C. L.: A recount of Ross Sea waters, Deep Sea Res. Pt. II, 56, 778-795, doi:10.1016/j.dsr2.2008.10.033, 2009.

Orsi, A. H., Whitworth III, T., and Nowlin Jr., W. D.: On the meridional extent and fronts of the Antarctic Circumpolar Current, Deep Sea Res. Pt. I, 42, 641-673, doi:10.1016/09670637(95)00021-W, 1995.

Orsi, A. H., Johnson, G., and Bullister, J.: Circulation, mixing, and production of Antarctic Bottom Water, Prog. Oceanogr., 43, 55109, 1999.

Orsi, A. H., Jacobs, S. S., Gordon, A. L., and Visbeck, M.: Cooling and ventilating the Abyssal Ocean, Geophys. Res. Lett., 28, 2923-2926, doi:10.1029/2001GL012830, 2001.

Petty, A. A., Feltham, D. L., and Holland, P. R.: Impact of Atmospheric Forcing on Antarctic Continental Shelf Water Masses, J. Phys. Oceanogr., 43, 920-940, doi:10.1175/JPO-D-12-0172.1, 2012

Pritchard, H. D., Ligtenberg, S. R. M., Fricker, H. A., Vaughan, D. G., van den Broeke, M. R., and Padman, L.: Antarctic icesheet loss driven by basal melting of ice shelves, Nature, 484, 502-505, doi:10.1038/nature10968, 2012.

Renfrew, I. A., King, J. C., and Markus, T.: Coastal polynyas in the southern Weddell Sea: Variability of the surface energy budget, J. Geophys. Res., 107, 16-1-16-22, doi:10.1029/2000JC000720, 2002.
Rignot, E., Jacobs, S., Mouginot, J., and Scheuchl, B.: Ice Shelf Melting Around Antarctica, Science, 341, 266-270, doi:10.1126/science.1235798, 2013.

Shepherd, A., Wingham, D., and Rignot, E.: Warm ocean is eroding West Antarctic Ice Sheet, Geophys. Res. Lett., 31, L23402, doi:10.1029/2004GL021106, 2004.

St-Laurent, P., Klinck, J. M., and Dinniman, M. S.: On the Role of Coastal Troughs in the Circulation of Warm Circumpolar Deep Water on Antarctic Shelves, J. Phys. Oceanogr., 43, 51-64, doi:10.1175/JPO-D-11-0237.1, 2012.

Talbot, M. H.: Oceanic environment of George VI Ice Shelf, Antarctic Peninsula, Ann. Glaciol., 11, 161-164, 1988.

Tamura, T., Ohshima, K. I., and Nihashi, S.: Mapping of sea ice production for Antarctic coastal polynyas, Geophys. Res. Lett., 35, L07606, doi:10.1029/2007GL032903, 2008.

Thoma, M., Jenkins, A., Holland, D., and Jacobs, S.: Modelling Circumpolar Deep Water intrusions on the Amundsen Sea continental shelf, Antarctica, Geophys. Res. Lett., 35, L18602, doi:10.1029/2008GL034939, 2008.

Timmermann, R., Beckmann, A., and Hellmer, H. H.: Simulations of ice-ocean dynamics in the Weddell Sea 1. Model configuration and validation, J. Geophys. Res., 107, 10-1-10-11, doi:10.1029/2000JC000741, 2002.

Timmermann, R., Le Brocq, A., Deen, T., Domack, E., Dutrieux, P., Galton-Fenzi, B., Hellmer, H., Humbert, A., Jansen, D., Jenkins, A., Lambrecht, A., Makinson, K., Niederjasper, F., Nitsche, F., Nøst, O. A., Smedsrud, L. H., and Smith, W. H. F.: A consistent data set of Antarctic ice sheet topography, cavity geometry, and global bathymetry, Earth Syst. Sci. Data, 2, 261-273, doi:10.5194/essd-2-261-2010, 2010.

van Lipzig, N. P. M., Turner, J., Colwell, S. R., and van Den Broeke, M. R.: The near-surface wind field over the Antarctic continent, Int. J. Climatol., 24, 1973-1982, doi:10.1002/joc.1090, 2004.

Wåhlin, A. K., Yuan, X., Björk, G., and Nohr, C.: Inflow of Warm Circumpolar Deep Water in the Central Amundsen Shelf, J. Phys. Oceanogr., 40, 1427-1434, doi:10.1175/2010JPO4431.1, 2010.

Walker, D. P., Brandon, M. A., Jenkins, A., Allen, J. T., Dowdeswell, J. A., and Evans, J.: Oceanic heat transport onto the Amundsen Sea shelf through a submarine glacial trough, Geophys. Res. Lett., 34, L02602, doi:10.1029/2006GL028154, 2007.

Wilchinsky, A. V. and Feltham, D. L.: Numerical simulation of the Filchner overflow, J. Geophys. Res., 114, C12012, doi:10.1029/2008JC005013, 2009.

Williams, G. D., Aoki, S., Jacobs, S. S., Rintoul, S. R., Tamura, T., and Bindoff, N. L.: Antarctic Bottom Water from the Adélie and George V Land coast, East Antarctica (140-149 ${ }^{\circ}$ E), J. Geophys. Res., 115, C04027, doi:10.1029/2009JC005812, 2010.

Yi, D., Zwally, H. J., and Robbins, J. W.: ICESat observations of seasonal and interannual variations of sea-ice freeboard and estimated thickness in the Weddell Sea, Antarctica (2003-2009), Ann. Glaciol., 52, 43-51, doi:10.3189/172756411795931480, 2011 